\title{
Exposure to more female peers widens the gender gap in STEM participation
}

\author{
Brenøe, Anne Ardila ; Zölitz, Ulf
}

\begin{abstract}
We investigate how high school gender composition affects students' participation in STEM at college. Using Danish administrative data, we exploit idiosyncratic within-school variation in gender composition. We find that having a larger proportion of female peers reduces women's probability of enrolling in and graduating from STEM programs. Men's STEM participation increases with more female peers present. In the long run, women exposed to more female peers are less likely to work in STEM occupations, earn less, and have more children. Our findings show that the school peer environment has lasting effects on occupational sorting, the gender wage gap, and fertility.
\end{abstract}

DOI: https://doi.org/10.1086/706646

Posted at the Zurich Open Repository and Archive, University of Zurich ZORA URL: https://doi.org/10.5167/uzh-198813

Journal Article

Published Version

Originally published at:

Brenøe, Anne Ardila; Zölitz, Ulf (2020). Exposure to more female peers widens the gender gap in STEM participation. Journal of Labor Economics, 38(4):1009-1054.

DOI: https://doi.org/10.1086/706646 


\title{
Exposure to More Female Peers Widens the Gender Gap in STEM Participation
}

\author{
Anne Ardila Brenøe, University of Zurich, Institute of Labor \\ Economics (IZA), and University of Copenhagen
}

Ulf Zölitz, University of Zurich, CESifo, CEPR, and IZA

\begin{abstract}
We investigate how high school gender composition affects students' participation in STEM at college. Using Danish administrative data, we exploit idiosyncratic within-school variation in gender composition. We find that having a larger proportion of female peers reduces women's probability of enrolling in and graduating from STEM programs. Men's STEM participation increases with more female peers present. In the long run, women exposed to more female peers are less likely to work in STEM occupations, earn less, and have more children. Our findings show that the school peer environment has lasting effects on occupational sorting, the gender wage gap, and fertility.
\end{abstract}

\section{Introduction}

In most OECD countries, women attain more education than men. Despite this reversal of the gender gap in education, large gender differences in

We are thankful for helpful comments and suggestions from Massimo Anelli, Mette Ejrnæs, Jan Feld, Mette Gørtz, Andrew Hill, Victor Lavy, Kjell Salvanes, and Denni Tommasi as well as seminar participants at the Melbourne Institute of Applied Economic and Social Research, the Institute for the Study of Labor (IZA) World Labor Conference, the International Workshop on Applied Economics of Education (IWAEE) conference in Catanzaro, Association for Education Finance

[Journal of Labor Economics, 2020, vol. 38, no. 4]

(C) 2020 by The University of Chicago. All rights reserved. 0734-306X/2020/3804-0004\$10.00

Submitted October 8, 2018; Accepted October 1, 2019; Electronically published August 20, 2020 
the choice of study field persist. Only $28 \%$ of college students in STEM (science, technology, engineering, and mathematics) studies are female (OECD 2016). As gender differences in ability do not seem to explain these differences (Kahn and Ginther 2017), we currently know little about why women remain underrepresented in STEM fields. It is important to improve our understanding of the origins of gender differences in study choices due to the potential consequences for both the individual and society. On an individual level, women with high math and science ability who do not participate in STEM forfeit higher lifetime earnings. On a societal level, when fewer women are part of the STEM workforce, society may be less innovative and thereby have worse long-run economic growth.

In this paper, we investigate how gender composition in high school affects men's and women's decisions to choose STEM fields in higher education. High school peers represent a central aspect of teenagers' social environment given that they interact daily for several years. During this time, students face one of their most crucial life choices. Therefore, peers may represent an important social force shaping specialization decisions. To investigate whether gender composition in high school affects the gender gap in STEM participation, we use Danish register data on all students entering the math track in high school between 1980 and 1994. The key advantage of this data set, in addition to its rich information on individuals' education and labor market outcomes, is that we can follow the entire student population over a period of 20 years after they entered high school. This allows us to identify the direct, delayed, and long-run consequences of high school peers.

Our strategy to identify the causal impact of gender composition on STEM choice builds on two empirical approaches that differ in their key identifying assumptions and interpretation of results. The first empirical approach exploits idiosyncratic cohort variation in the proportion of female students within schools across cohorts after taking out school fixed effects, cohort fixed effects, and school-specific time trends. ${ }^{1}$ The second empirical approach extends this model by including cohort-by-school fixed effects, thereby examining whether the proportion of female peers differentially affects men and women within the same school cohort. This identification

and Policy (AEFP) 2017, Danish Graduate Programme in Economics (DGPE) 2016, the University of Copenhagen, and the Copenhagen Education Network. Contact the corresponding author, Ulf Zölitz, at ulf.zoelitz@econ.uzh.ch. Information concerning access to the data used in this paper is available as supplemental material online.

${ }^{1}$ This identification strategy is similar to that of Anelli and Peri (2017), Hill (2017), Hoxby (2000), and Lavy and Schlosser (2011), who exploit idiosyncratic variation in the proportion of female students within schools. 
strategy thus answers whether the gender gap in STEM choice grows or shrinks as the gender composition changes. ${ }^{2}$

The key identifying assumption for our first strategy is that year-to-year variations in the proportion of female students are exogenous to factors affecting STEM choice, conditional on school fixed effects, cohort fixed effects, and school-specific time trends. To assess the credibility of this identifying assumption, we conduct an extensive set of balancing checks, testing whether changes in gender composition are associated with student characteristics. Using a large set of student background characteristics from the register data, we show that gender composition does not systematically relate to the characteristics of students selecting into the specific school cohort, conditional on school and cohort fixed effects. ${ }^{3}$ While this balancing test provides strong support for our key identifying assumption, it remains theoretically possible that students sort into schools on the basis of factors correlated with STEM choice that are both time variant and unobservable in the register data. Although it is difficult to think of mechanisms that would create these unobservable time-variant school selection patterns, our second empirical approach addresses this concern. The inclusion of fixed effects for each cohort-by-school cell alleviates remaining potential concerns, as we can control for the exact level at which selection based on time variant and unobservable characteristics would take place. ${ }^{4}$ Both of our empirical approaches yield qualitatively similar results.

Our results show that women exposed to a higher proportion of female peers become less likely to enroll in STEM fields and more likely to enter health-related studies in college. Men are overall less affected but also behave more gender stereotypically when more female peers are present: they become more likely to enroll in STEM studies and less likely to enter healthrelated studies. These peer effects in field of study choice are statistically and economically significant. A 10 percentage point increase in the proportion of female high school peers lowers women's probability of enrolling

2 This identification strategy is used by Merlino, Steinhardt, and Wren-Lewis (2019) to test whether the peer composition in high school affects the probability of interracial romantic relationships. Our strategy is analogous to the literature that estimates differences between siblings, including sibling fixed effects (instead of cohort-by-school fixed effects), by, for instance, considering how sisters (women) and brothers (men) are differentially affected by the childhood family environment (high school peer composition; Brenøe and Lundberg 2017; Autor et al. 2019).

${ }^{3}$ We also test and reject the possibility that the proportion of female students enrolling in a given school is autocorrelated over time. Put differently, we find no evidence that the proportion of female students in year $t-1$ predicts the proportion female peers in year $t$.

${ }^{4}$ It is important to note that results from regressions including cohort-by-school fixed effects no longer identify whether an increase in the proportion of female peers affects the levels of STEM enrollment for men and women but instead identify gender differences in response to changes in the peer environment. 
in STEM studies by 1.4 percentage points, which is equivalent to a $6.4 \%$ decrease from the baseline. For men, a similar change in the gender composition raises STEM enrollment by 0.9 percentage points $(2.4 \%)$. These peer effects not only exacerbate gender differences in STEM enrollment but also translate into an increased gender gap in STEM degree completion. In our most conservative model, which includes cohort-by-schools fixed effects, we find that a 10 percentage point increase in high school female peers raises the gender gap in STEM degree completion by 2 percentage points, corresponding to a $17 \%$ increase.

We shed some light on possible mechanisms behind this finding by studying how peer gender affects student performance, measured as high school grade point average (GPA). Since high-achieving students are generally more likely to enter STEM fields and it has been shown that peers affect performance in high school (e.g., Hoxby 2000; Lavy and Schlosser 2011), one possible mechanism is that the gender composition affects men's and women's preparedness for STEM studies. We find evidence in support of this mechanism: having more female peers alters the gender gap in high school GPA in favor of men, which may give women - who consider their comparative advantage - reason to believe that they are less prepared for college studies in STEM. When considering heterogeneous effects by parental background, we provide two pieces of evidence that suggest that information about college in general and STEM studies in particular can counter peer influences to some degree. First, students with college-educated parents are less affected by peers. Second and more strikingly, the gender peer composition does not influence women with STEM-educated mothers (i.e., women who have a salient female role model at home).

Our long-run results on labor market trajectories show that the peer effects in study choice lead women and men to systematically different career paths. Not only are women who are exposed to more female high school peers less likely to choose STEM studies, they are also less likely to work in STEM occupations, and they have lower earnings at age 36. A 10 percentage point increase in the proportion of female high school peers lowers women's probability of working in STEM occupations by $4 \%$ and increases the gender wage gap by $5 \%$. These results imply that high school peers and their influence on college major choice have lasting and economically significant consequences for occupational segregation and earnings.

Finally, we study how peers affect individuals' fertility outcomes and find that women exposed to more female peers have more children by age 36 . For the interpretation of this effect, it is relevant to note that peer gender composition may affect fertility preferences either directly or indirectly. An indirect impact could arise, for instance, if STEM careers are associated with less familyfriendly work environments. Although we ultimately cannot disentangle whether reduced fertility indeed is due to entering STEM fields, it is possible that it might be harder to combine having children with work obligations in 
STEM occupations. Another important possibility that might help explain the increase in the gender wage gap when having more female peers is that having (more) children reduces earnings for women (Lundborg, Plug, and Rasmussen 2017; Kleven, Landais, and Søgaard 2018). In such cases, lower female earnings should not be attributed to staying out of STEM fields per se but would instead be a consequence of the "career cost of children" (Adda, Dustmann, and Stevens 2017). ${ }^{5}$

In the existing literature, only a handful of related studies investigate how the gender of peers in high school influences educational choices. ${ }^{6}$ Lavy and Schlosser (2011) find that both male and female students perform better and take more science courses in high school when exposed to more female peers. In contrast to this, we find that women become less likely to enter subsequent STEM studies and that only men perform better in high school with more female peers present. While Lavy and Schlosser (2011) provide intriguing evidence on the underlying mechanisms, it is not possible to study long-run effects on study choice, occupational sorting, fertility, or earnings in their setting.

Closely related to our work, Anelli and Peri (2017) show that the gender composition in high school has an effect on men's, but not on women's, study choice in college. While Anelli and Peri leverage random assignment of students to classes for identification, we use idiosyncratic cohort variation in female peers within schools. Anelli and Peri (2017) find that men attending high school classes with more than $80 \%$ male peers are more likely to enroll in predominantly male college majors. ${ }^{7}$ Contrary to our findings, these effects do not persist into actual degree completion or affect earnings. ${ }^{8}$ While Anelli and Peri (2017) focus on the effect of being in a very maledominated environment - at least $80 \%$ male peers - we consider a continuous measure of female peers and thus identify effects at a different margin of the gender composition.

${ }^{5}$ Related to this point, if peers shape individuals' preferences for children-even before those children are born - men and women may choose more family-friendly careers outside of STEM that can facilitate their family planning. In this case, the choice of study field might reflect the changed fertility preferences.

${ }^{6}$ Starting with Hoxby (2000), a different but related strand of literature investigates how gender composition affects student performance. For important studies of the impact of peer gender on performance, see Whitmore (2005), Lavy and Schlosser (2011), De Giorgi, Pellizzari, and Woolston (2012), Oosterbeek and Ewijk (2014), and Hill (2015).

${ }^{7}$ In contrast to Anelli and Peri (2017), who consider enrollment in and graduation from programs in engineering, economics, and business, we study whether students choose any STEM field, which also includes science, technology, and mathematics, and follow each student for 20 years after high school entry.

${ }^{8}$ While Anelli and Peri (2017) observe only earnings in the year 2005 for a part of their sample, we utilize panel data on earnings and employment and thereby follow the earnings trajectory at an annual level through age 36 for all individuals in our sample. 
At the college level, Hill (2017) presents suggestive evidence that women exposed to a university cohort with more female peers have a lower probability of majoring in STEM fields. Similarly, Zölitz and Feld (forthcoming) show that women become less likely to major in male-dominated subfields when they are randomly assigned to university sections containing more female peers. On the contrary, Schneeweis and Zweimüller (2012) show that a larger share of female peers in lower secondary vocational school increases girls' propensity to choose male-dominated school types. Based on the existing literature, which presents mixed evidence from a variety of different settings, it is not clear how gender composition affects specialization decisions. ${ }^{9}$ Finally, our paper also relates to a different strand of the literature studying how the social environment shapes fertility decisions (Kuziemko 2006; Balbo and Barban 2014; Ciliberto et al. 2016; Brenøe 2018), which previously has not been examined by the gender peer effects literature.

This paper contributes to the literature in three important ways. First, we are the first to document that gender composition in high school affects STEM participation in college. Second, we provide previously undocumented comprehensive evidence on the long-run occupational consequences of high school peers. Our ability to follow students in the Danish administrative data over the course of 20 years after high school entry distinguishes this study from existing work that mostly studies the short- or medium-run impact of peers. Third and more broadly, this paper contributes to a better understanding of the origins of gender differences in educational choices and labor market outcomes. While we do not offer a universal explanation for women's underrepresentation in STEM, we identify one relevant factor that contributes to this gap. To the extent that our results for Denmark replicate in other environments, this paper shows that the gender composition of high school peers represents an important aspect of the social environment that shapes individuals' preferences for field of study, occupation, and fertility.

\section{Institutional Background and Data}

In this study, we use Danish administrative data covering the entire population of first-year high school students enrolled in the math track from 1980 through 1994. This group of students represents the student population for whom the choice of specialization within STEM fields in college is highly relevant. The key advantage of our data set is that it contains rich background information and allows us to follow individuals over the course of 20 years after high school entry. We link the administrative data on high school students to annual data on educational enrollment and degree completion, which

9 The related literature on the impact of single-sex education also provides mixed results. While Jackson (2016) finds that single-sex secondary schools cause girls to take fewer math and science courses, other studies find no impact (Sohn 2016) or a positive effect (Lee et al. 2014 and studies cited therein). 
also contain detailed information on the type, level, and field of education as well as labor market outcomes up to 20 years after entering high school. In the rest of this section, we introduce the institutional setting, describe the estimation sample, and present summary statistics on the key variables of the analysis.

\section{A. Institutional Background}

Children in Denmark enter primary school the year they turn 7 years old and are required to attend school through grade $9 .{ }^{10}$ Attendance at grade 10, which is a formal continuation of primary school, is optional. In their final year of primary school, students apply for secondary school. When applying for secondary education, students can choose between academic high schools, which take 3 years, or vocational programs, which typically take 4 years. ${ }^{11}$ The general academic high school, which represents the most popular type of academic high school, has two tracks: math and language..$^{12}$ The curriculum for the two tracks is significantly different, with the math track preparing students for tertiary education within STEM fields or more quantitativeoriented social science programs. In contrast, the language track prepares students for tertiary education within humanities or less quantitative-oriented social science programs and does not offer students the courses required by most university STEM programs. Academic high schools normally offer both tracks; approximately two-thirds of the students attend the math track and the remaining one-third attend the language track, which is typically female dominated. ${ }^{13}$ Students in both tracks share the same building and social events, such as Friday bars or sports competitions. The two tracks typically will not have any classes together, although it is possible that some students take an elective course within the other track, such as a second foreign language. Therefore, students within the same track are likely to be the most relevant peer group for subsequent educational decisions. ${ }^{14}$

In the high school application process, students specify their first, second, and third choice of a combination of specific high schools and track. Students are qualified for high school admission if they have completed at least 9 years

${ }^{10}$ For the cohorts we study, it was not mandatory to attend a kindergarten class (grade 0), but most children did so.

${ }_{11}$ Academic high schools fall broadly into three branches: general, commercial (bøjere handelseksamen, or HHX), and technical (bøjere teknisk eksamen, or HTX).

${ }_{12}$ During the period we study, about $18 \%$ of each birth cohort enrolled in the math track, and about $45 \%$ of students within the math track are female. Both the share of math-track students and the share of women within the math track were relatively constant over the period our estimation sample covers.

${ }^{13}$ Approximately $80 \%$ of language-track students are female. All schools are mixed sex.

${ }^{14}$ Table 6 considers different definitions of the relevant peer group. 
of education with satisfactory results and if teachers confirm their qualification. ${ }^{15}$ All applicants qualified according to these criteria are guaranteed admission to a high school in their county of residence, and admission does not depend on academic achievement in primary school. If there is insufficient capacity at all three of the student's preferred schools, the allocation committee in their home county admits them to another school after considering commuting time. ${ }^{16}$ Schools experiencing capacity problems are concentrated in metropolitan areas. Students submit the application in the winter of their last year in primary school and only learn of the gender composition in their actual high school track cohort on the first day in high school in August, 6 months later.

After high school completion, many students take one or two gap years before entering college. ${ }^{17}$ During the period of study, students chose a specialization within their track at the end of the first year in high school. Before high school reforms in 1988, all high schools were required to offer the same few specialization packages (for details, see Joensen and Nielsen 2016). After the reforms, high schools were still required to offer certain courses (including courses required for all types of university programs) but had more leeway to offer a wider spectrum of courses, and students had more options to combine different types of courses. Therefore, a certain gender composition within a school would not directly have affected the course availability for students.

In the college application process, students apply for a specific field of study and a specific institution and can indicate up to eight institutionspecific study programs. A diploma from an academic high school is required for admission. Admission depends on high school GPA; however, most STEM programs have no or very low GPA cutoffs, and almost all eligible students who apply are admitted. While GPA does not restrict students' STEM study choice, certain high school courses, such as advanced mathematics and intermediate physics and chemistry, are prerequisites for STEM college majors. In other words, to be eligible to enter STEM college studies, a math-track high school diploma is almost a necessity. ${ }^{18}$ Throughout this paper, we therefore focus on students within the high school math trackstudents for whom entering STEM fields in college represent a relevant career option. Among students within the math track, $30 \%$ later decide to enroll in a STEM program; students from other high school tracks rarely choose

${ }^{15}$ If these conditions are not met, students can still qualify for school admission if they pass an entrance exam.

${ }_{16}$ According to conversations with school principals active during our observation period, admission committees did not consider the gender of applicants during the admission process.

${ }^{17}$ We define college as professional and academic tertiary education.

${ }^{18}$ However, it is possible to take extra courses after high school graduation to meet the entry criteria. 
STEM studies. ${ }^{19}$ Math-track students thus represent the most relevant margin for increasing women's STEM participation.

\section{B. Estimation Sample}

We exclude students with missing values for gender and age $(0.8 \%$ of students) and students who were not between 14 and 19 years old when entering the general high school (less than $0.01 \%$ ). We further restrict the estimation sample to schools in which at least $95 \%$ of students in a given cohort are 14-19 years old and exclude schools with very small cohort sizes of less than 10 students in a given year (6.1\% of students). We apply these restrictions to exclude schools that mainly offer evening education or single courses; these schools target older part-time students who are, in many cases, working at the same time. Finally, we restrict the sample to schools that have been in existence and have admitted students for at least four consecutive years (excluding $0.6 \%$ of students). None of these data restrictions qualitatively change the results. ${ }^{20}$

\section{Summary Statistics}

Table 1 provides an overview of the summary statistics. Our estimation sample consists of 182,211 students attending 127 different schools over a period of 15 years, resulting in a total of 1,877 school cohort observations. Forty-five percent of the students are female, and the average cohort size in the math track is 108 students.

Panel A in table 1 shows the student outcomes we consider in this paper. The primary outcomes of interest are indicators for whether the student enrolls in a STEM study field and whether their college degree is within STEM fields at the college level or higher. ${ }^{21}$ To classify STEM study programs, we follow the International Standard Classification of Education (ISCED) classification system (UIS 2012). STEM degrees are thus studies within the following ISCED fields: natural sciences, mathematics, and statistics (ISCED-05), information and communication technologies (ISCED-06), and engineering, manufacturing, and construction (ISCED-07). To examine which fields within STEM drive the effects, we also split STEM into four subfields: (1) biology, (2) math and physics, (3) information and communication technology (ICT) and engineering, and (4) manufacturing and construction. Additionally, we consider the probability of completing the highest degree within

\footnotetext{
${ }^{19}$ For comparison, only $4.6 \%$ of STEM college graduates attended the high school language track.

${ }^{20}$ Results are available on request.

${ }^{21}$ Throughout the paper, we use the field of the highest obtained degree to construct measures of STEM completion. The enrollment variables are indicators for the student's ever having been enrolled in the respective study at the college level or higher. If we instead consider the field of first or last enrollment, we find very similar results throughout.
} 


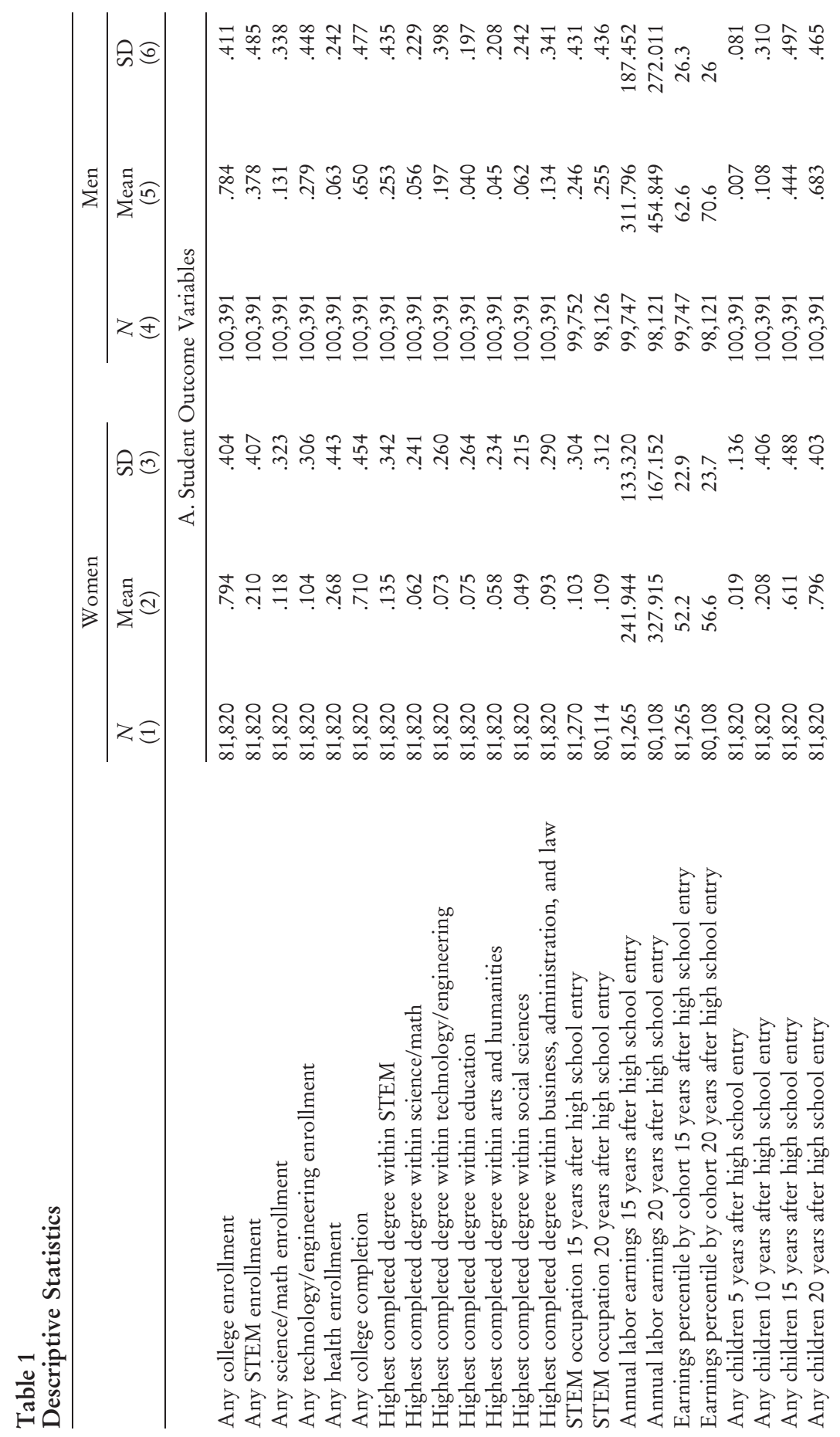




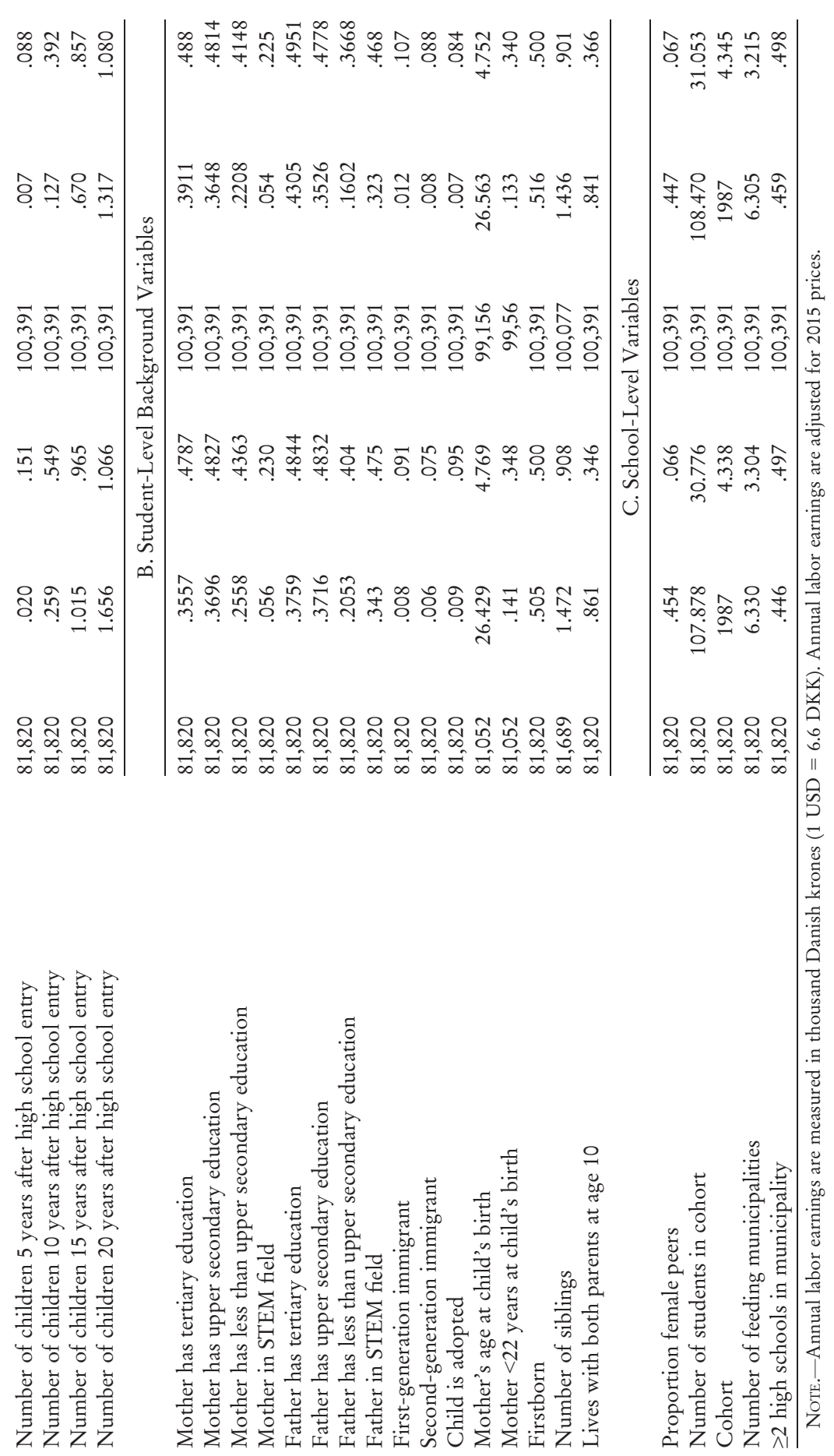


health sciences (ISCED-091), education (ISCED-01), arts/humanities (ISCED-02), social sciences (ISCED-031), and business/law (ISCED-04).

From the total sample, $79 \%$ of all students enroll in college after high school. Table 1 shows that only $21 \%$ of female and $38 \%$ of male high school students subsequently enroll in STEM studies. This gender gap persists in STEM completion rates: while only $14 \%$ of women graduate with a STEM degree, $25 \%$ of men do so. Labor market outcomes show that 20 years after high school entry, $11 \%$ of women and $26 \%$ of men work in a STEM occupation. ${ }^{22}$

Panel B in table 1 provides an overview of the student demographic and parental background characteristics we use in the regression analysis as controls, and panel C shows school-level variables. The key peer variable of interest is the proportion of female peers at the time of high school entry, which we construct at the cohort-school-track level excluding the individual himself or herself. As less than 1\% of students change to another high school or track, this group of peers represents the social group in which students interact over a 3-year period. Students are, on average, exposed to $45 \%$ female peers. A 1 standard deviation change in the proportion of female peers is equivalent to 7.0 percentage points.

Figure 1 shows the raw correlations between the proportion of female peers and the probability of completing a STEM degree. For women, a higher proportion of female peers is correlated with a lower probability of obtaining a STEM degree. For men, on the contrary, we observe a positive correlation between the proportion of female peers and STEM degree completion. These raw associations suggest a fairly linear relationship. Although these correlations are purely descriptive, they foreshadow the results of our regression analysis.

\section{Empirical Strategy}

The fundamental threat to identification of peer effects arises from student sorting at various institutional levels. Parents select into neighborhoods, students select into schools, and within schools students may select into classrooms or be assigned to tracks. As students are typically not assigned to schools at random, the existing peer effects studies try to overcome this identification problem by exploiting natural variation in cohort composition within a given school across time (Hoxby 2000; Hanushek et al. 2003; Lefgren 2004; Hoxby and Weingarth 2005; Vigdor and Nechyba 2006; Carrell and Hoekstra 2010; Bifulco, Fletcher, and Ross 2011; Carrell,

${ }^{22}$ We use the Danish version of the International Standard Classification of Occupations (DISCO) and construct an indicator for working in STEM if the individual works in a high-skilled occupation within STEM for at least half the years observed, 11-15 and 16-20 years after high school entry, respectively. All results remain qualitatively the same when using indicators for whether the mode occupation is within STEM for the considered periods. 


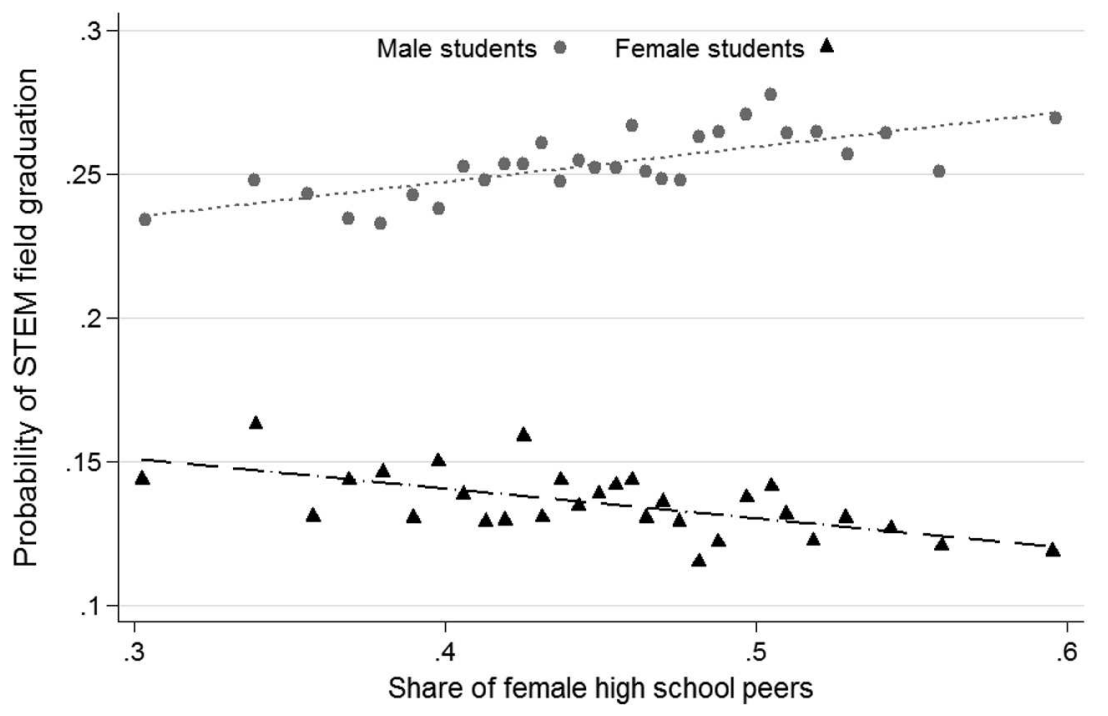

FIG. 1.-Correlation between proportion of female peers and STEM degree completion. The graph shows a bin scatterplot by gender using 30 bins. STEM degree is measured as the highest completed degree at the college level or higher 20 years after high school entry.

Hoekstra, and Kuka 2018). Although this identification strategy addresses the issue of endogenous, time-constant student sorting into schools, it is vulnerable to school-specific (dynamic) time trends that may alter both the peer composition and the outcome of interest. More recent peer effects studies respond to this concern with the inclusion of school-specific time trends-linear, quadratic, and cubic (Lavy and Schlosser 2011; Lavy, Paserman, and Schlosser 2012; Schneeweis and Zweimueller 2012; Hill 2017). For identification, these studies exploit the deviation in peer composition from its longterm time trend within a school. This approach has the advantage of controlling for unobserved factors correlated with time trends in school composition that may confound peer effects in schools.

Our first empirical approach is similar to the approach in the literature discussed in the previous paragraph and shares the key identifying assumption that the variation in the peer composition is exogenous after taking out school fixed effects, cohort fixed effects, and school-specific time trends. In our second empirical approach, we estimate an even more restrictive model by including fixed effects for each cohort-by-school cell, thereby alleviating all remaining potential concerns regarding selection. In the following, we describe our empirical model, our two identification strategies, and the underlying assumptions in more detail. 


\section{A. Empirical Model}

Our main empirical model is

$$
\begin{aligned}
Y_{i s c}= & \beta_{1} \text { Female }_{i} \times \text { PropFemalePeers }_{i s c}+\beta_{2} \text { Male }_{i} \\
& \times \text { PropFemalePeers }_{i s c}+\beta_{3} \text { Female }_{i}+C_{i s c} \gamma^{\prime}+e_{i s c},
\end{aligned}
$$

where $Y_{i s c}$ is the outcome of student $i$ attending school $s$ in cohort $c$. The main outcomes we consider are STEM participation, the individuals' earnings percentile by age and birth cohort, and fertility. In our data, each individual represents one observation. The treatment variable of interest is PropFemalePeers which represents the proportion of female peers individual $i$ is exposed to in his or her school $s$ and cohort $c$. To investigate heterogeneity by gender, we interact the proportion of female peers with the indicator variables Female $_{i}$ and Male, which refer to the students' own gender.

Thus, $\beta_{1}$ captures to what degree women's study choices and labor market outcomes are affected by the peer gender composition in their high school, $\beta_{2}$ captures the equivalent impact for men, and $\beta_{3}$ captures the gender gap in outcomes conditional on controls. The term $C_{i s c}$ represents a vector of school and cohort fixed effects as well as individual and peer characteristics that we gradually add when estimating equation (1). The inclusion of high school fixed effects accounts for time-invariant endogenous sorting into schools, and cohort fixed effects control for confounding factors at the national level, affecting all students in a given cohort. To account for unobserved time-variant school characteristics correlated with both changes in the proportion of female peers and educational choices for students within the same schools, we add school-specific linear, quadratic, and cubic time trends to the vector $C_{i s c}$.

In our more conservative models, the vector $C_{i s c}$ includes the following additional student and peer average characteristics, which do not significantly alter our estimates: six indicator variables for mother's and father's highest educational degree and 18 indicators for their field of education; ${ }^{23}$ indicators for first- and second-generation immigrant; a "traditional family" indicator that equals 1 if the student lives with both parents at age 10; dummies for student age at the time of high school start; mother's age at birth and its squared term; an indicator for having a young mother (<22 years at birth); an indicator for whether the child is firstborn; family size and its squared term; and a dummy for whether the individual is adopted. ${ }^{24}$ Additionally, we control for up to

${ }^{23}$ For each parent, we include nine dummies indicating whether his or her highest education is within ISCED fields 1-9.

${ }^{24}$ As individual controls, we additionally always control for dummies indicating the number of years after high school entry the individual was last observed in the education registry for our education models and dummies for the number of years observed within the given period for labor market outcomes. The inclusion of these 
third-degree polynomials of cohort size, as peer composition may potentially be correlated with cohort size (Epple and Romano 2011). ${ }^{25}$ Finally, the vector includes the proportion of female students in the language track in the same high school cohort and controls for the high school curriculum experiment that took place in Denmark in the 1980s (for more details regarding the experiment, see Joensen and Nielsen 2016). The main purpose of including this large vector of control variables is to test how sensitive our results are to the inclusion of these variables. In the spirit of Altonji, Elder, and Taber (2005), changes in the coefficients of interest that result from including controls may inform us about the degree to which omitted unobservable factors may affect our results. To allow students' outcomes to correlate within their group of peers, we cluster the standard errors, $e_{i s c}$ at the school cohort level. ${ }^{26}$

The key identifying assumption for our first approach to yield causal estimates of $\beta_{1}$ and $\beta_{2}$ in equation (1) is that no omitted variable exists that fulfills all of the following four requirements:

1. time variant and school specific;

2. not captured by school-specific time trends;

3. correlated with both the peer composition and the outcome of interest; and

4. not included in the extensive set of individual- and peer-level control variables observed in the administrative data sets.

While it is difficult to think of any plausible mechanism that would create a violation of this type, the existence of such factors remains possible. To assess the credibility that such factors do not exist, we conduct an extensive set

controls reduces measurement errors given that the annual data do not record individuals living abroad.

${ }^{25}$ Moreover, we include indicators for whether the school experiences a change of more than 30 students or more than $50 \%$ in the cohort size compared with the previous cohort and up to 2-period lags of these variables. Given that a high school degree takes 3 years, we include these 2 -year lags to account for the possibility that a student's outcome was affected despite the fact that the inflow did not happen in his or her cohort. We furthermore control for the number of students from the cohort who are not in the age range of 14-19 years and for the number of students in the cohort who have missing gender and age information. Reasons for missing information on gender or age include that the person does not live in Denmark but attends a Danish school (e.g., lives close to the Danish-German border) or that the person resides in the country on a diplomat visa. None of these included control variables qualitatively change our results.

${ }^{26}$ Angrist (2014) shows that with chance variation in peer groups, measurement error can bias peer effects estimates. Feld and Zölitz (2017) study this issue in more depth and show that classical measurement error can lead to overestimation of peer effects. Because we observe the students' gender in administrative registries, gender is arguably measured without error, and our estimates should thus be free from upward bias arising from measurement error. 
of balancing checks in section IV in which we test whether the peer composition in a school cohort is systematically related to a large vector of highquality measures of student background characteristics observable in the register data. Although these balancing tests strongly support our key identifying assumption, we also provide results from a second empirical approach. Our second approach addresses the possibility of identification problems arising from unobservable, time-variant, and school-specific omitted variables not captured by school-specific time trends that may be correlated with both the peer composition and the outcome of interest.

In our second empirical approach, we extend equation (1) by including an additional set of fixed effects for each cohort-by-school cell. The inclusion of these cohort-by-school fixed effects alleviates potential remaining concerns, as we control for the exact level at which selection based on time variant and unobservable characteristics would take place. Importantly, estimates from this type of model no longer identify whether an increase in the proportion of female peers will affect the overall number of women and men who choose a STEM program but instead identify a gender difference in the response to changes in the peer environment. These estimates thus answer whether the proportion of female high school peers affects gender gaps in STEM participation and earnings.

\section{Balancing Tests}

To assess the plausibility of our key identifying assumption that timevariant and unobservable factors are not driving our results, we test whether we observe systematic selection on the basis of a wide range of observable student characteristics. Our key identifying assumption would be violated if, for example, women select into a specific school on the basis of the expectation of a higher or lower proportion of female peers within that school cohort. In our first balancing test, we test whether students' own gender is correlated with the proportion of female peers, conditional on cohort and school fixed effects. This test closely follows the randomization check proposed by Guryan, Kroft, and Notowidigdo (2009) and controls for the school-level leave-out mean of the proportion of female peers across cohorts within the school to account for the mechanical relationship between own gender and peer gender. Table 2 shows that the proportion of female high school peers is not systematically related to students' own gender. The point estimate is precisely estimated and not distinguishable from zero. The inclusion of individual and school-level controls as well as up to cubic time trends in columns $2-5$ does not significantly alter the point estimate.

While table 2 rejects sorting based on gender, it may still be possible that students sort into schools with a high proportion of female peers on the basis of characteristics other than gender. The availability of a large set of high-quality measures of student background characteristics in the Danish administrative 


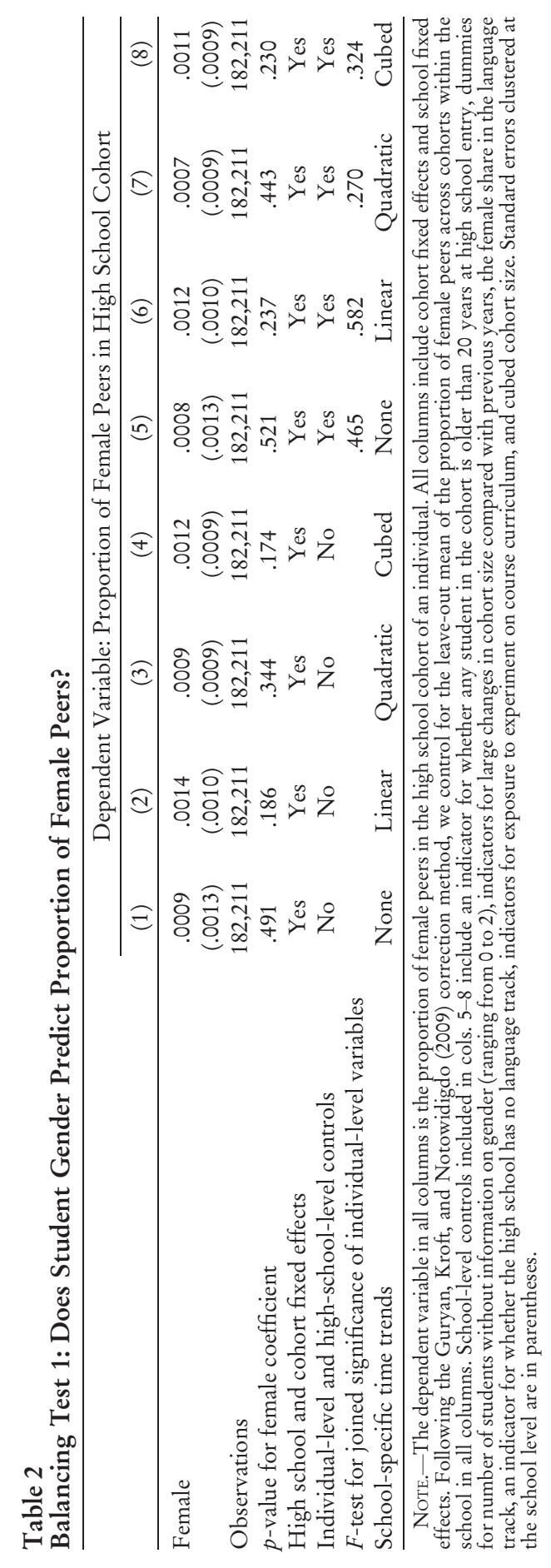


registries - typically not observable in other studies - allows us to rigorously test for this possibility.

In our next balancing test, we determine in how many cases student characteristics are significantly correlated with the proportion of female peers. Table 3 summarizes the significance of the point estimates from a total of 190 separate bivariate regressions, which test whether the proportion of female peers is related to student characteristics conditional on cohort and school fixed effects. Each column presents the results for a different set of control variables and school-specific time trends. Table A1 shows the full balancing test with all 190 coefficients. As expected when running a large number of regressions testing multiple hypotheses, some coefficients are statistically significant. In the absence of systematic sorting, we would expect $10 \%$ of coefficients to be statistically significant at the $10 \%$ significance level, $5 \%$ at the $5 \%$ level, and $1 \%$ at the $1 \%$ level simply as a result of chance. The share of significant coefficients is close to or below the respective expectation for all three significance levels. Table 3 shows that $1.1 \%$ of the estimates are statistically significant at the $1 \%$ level, $2.1 \%$ are significant at the $5 \%$ level, and $8.9 \%$ are significant at the $10 \%$ level. These balancing tests suggest that the proportion of female peers is as good as random and provide strong support for our key identification assumption. Without systematic cohort and school-specific sorting on this large set of observables, it appears highly unlikely that unobservable time-variant factors create unobserved sorting patterns.

Next, we test whether the proportion of female peers enrolling at a given school is autocorrelated over time. We do this by running 127 separate

Table 3

Balancing Test 2: Does Proportion of Female Peers Predict Student Background Characteristics?

\begin{tabular}{lcccccc}
\hline & & & & & \multicolumn{2}{c}{$\begin{array}{c}\text { Across All } \\
\text { Models } \\
\end{array}$} \\
& $(1)$ & $(2)$ & $(3)$ & $(4)$ & $(5)$ & $(6)$ \\
\hline Number of performed tests & 38 & 38 & 38 & 38 & 38 & 190 \\
Number significant at 1\% level & 1 & 1 & 0 & 0 & 0 & 2 \\
Number significant at 5\% level & 1 & 1 & 0 & 1 & 1 & 4 \\
Number significant at 10\% level & 4 & 5 & 2 & 4 & 2 & 17 \\
Share significant at 1\% & .026 & .026 & .000 & .000 & .000 & .011 \\
Share significant at 5\% & .026 & .026 & .000 & .026 & .026 & .021 \\
Share significant at 10\% & .105 & .132 & .053 & .105 & .053 & .089 \\
School-level controls & No & Yes & Yes & Yes & Yes & \\
School-specific time trends & None & None & Linear & Quadratic & Cubed & \\
\hline
\end{tabular}

NotE.-This table is based on 190 separate ordinary least squares regressions shown in table A1. All regressions include cohort fixed effects and school fixed effects. School-level controls included in cols. 2-5 include an indicator for whether any student in the cohort is older than 20 years at high school entry, dummies for number of students without information on gender (ranging from 0 to 2), indicators for large changes in cohort size compared with previous years, the female share in the language track, an indicator for whether the high school has no language track, indicators for exposure to experiment on course curriculum, and cubed cohort size. 
regressions that separately test, for each individual school, whether the proportion of female students at time $t$ is correlated with the proportion of female peers who enrolled at $t-1$. Although such school-level autocorrelation would not impose a threat to our identification strategy, as it would be captured by the included school-specific time trends, the existence of such school-specific time dynamics may point to the existence of other unobservable time-variant confounders. Table 4 provides a summary of this exercise and reports the proportion of schools for which we find significant autocorrelation in the proportion of female students. For all significance levels, the share of schools for which the lag of female peers significantly predicts the proportion of female peers is close to what we would expect in the absence of autocorrelation. Across all models, $0.98 \%$ of the school-level regressions are significant at the $1 \%$ level, $3.35 \%$ are significant at the $5 \%$ level, and $8.86 \%$ are significant at the $10 \%$ level. Thus, we find no evidence that the proportion of female students enrolling in a given school is autocorrelated over time.

As another randomization check, we inspect whether the variation in the proportion of female peers, which we empirically exploit in this paper, is consistent with variation that we would expect with natural random fluctuations. Figure 2 plots the proportion of female peers at the school level after residualizing on cohort and school fixed effects and school-specific linear time trends. Figure 2 shows that these deviations in the proportion of female peers closely follow the normal distribution, which we plot for comparison. The shape of the distribution further supports the idea that the proportion of female peers is as good as random, conditional on the included controls.

As a final randomization check, we test whether the proportion of female peers in the math track correlates with the proportion of female peers in the language track within a given school. If the year-to-year fluctuations are indeed random, we would not expect the share of female peers to be correlated

Table 4

Balancing Test 3: School-Level Autocorrelation in the Proportion of Female Students

For What Proportion of Schools Does the Proportion of Female Students at $t-1$ Significantly Predict the Proportion of Female Students at $t$ ?

Across

\begin{tabular}{lccccc} 
Proportion of School Coefficients & $(1)$ & $(2)$ & $(3)$ & $(4)$ & $\begin{array}{c}\text { All Models } \\
(5)\end{array}$ \\
\hline Significant at 1\% level & 1.57 & .79 & .79 & .79 & .98 \\
Significant at 5\% level & 2.36 & 2.36 & 3.15 & 5.51 & 3.35 \\
Significant at 10\% level & 6.30 & 5.51 & 8.66 & 14.96 & 8.86 \\
School-specific time trends & None & Linear & Quadratic & Cubed & \\
\hline
\end{tabular}

NOTE.-Values are percentages. This table provides summary statistics of significance for 127 separate bivariate school-level regressions that include only the respective school-specific trend variable(s). 


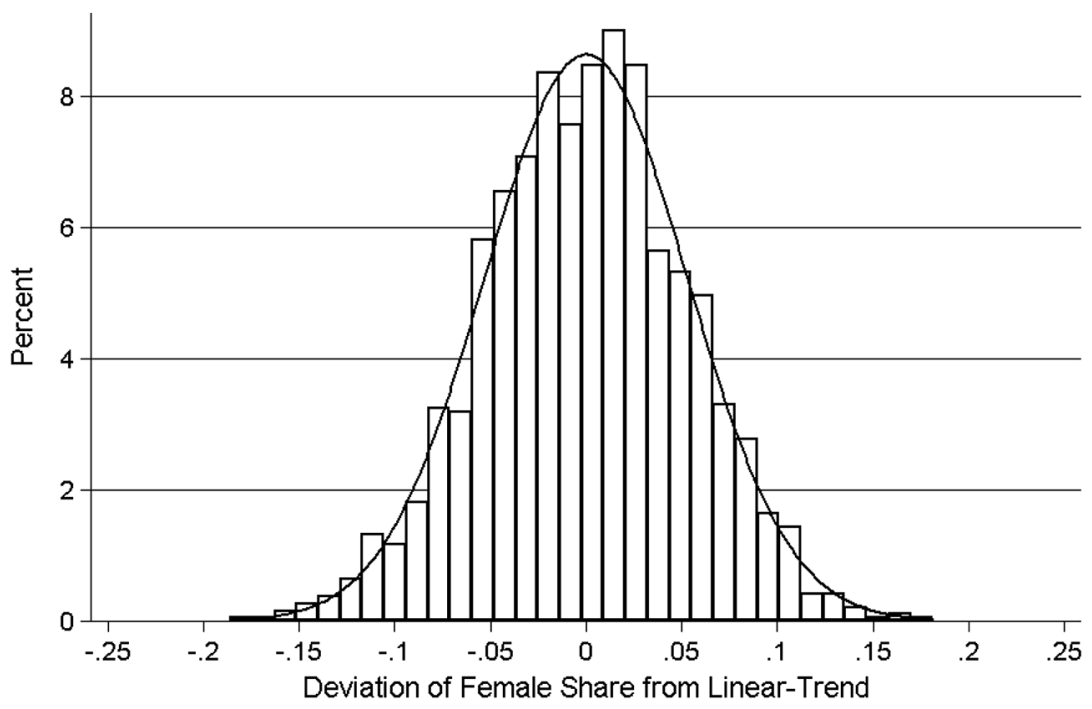

FIG. 2.-Year-to-year variation in the proportion of female high school peers within high schools. This graph illustrates the year-to-year variation in the proportion of female high school peers within high schools, plotted along with the normal distribution. More precisely, it plots the predicted proportion of female peers at the school cohort level from a regression regressing the proportion of female peers on cohort and school fixed effects and school-specific linear time trends. Each high school cohort represents one observation.

across tracks. Table 5 shows estimation results for the correlation between the proportion of female peers in the math and language tracks within schools. Reassuringly, we do not find any correlation between the female peer shares in the two tracks, independent of the set of included control variables.

In sum, the extensive set of balancing checks in this section provides strong support for our key identifying assumption. The evidence shown

Table 5

Correlation between Proportion of Female Peers in Math and Language Tracks

\begin{tabular}{lccc}
\hline & \multicolumn{3}{c}{ Proportion Female Peers in Language Track } \\
\cline { 2 - 4 } & $(1)$ & $(2)$ & $(3)$ \\
\hline Proportion female peers in language track & -.015 & -.017 & -.035 \\
& $(.027)$ & $(.026)$ & $(.026)$ \\
$N$ & 1,866 & 1,866 & 1,866 \\
Mean & .449 & .449 & .449 \\
Individual- and peer-level controls & No & Yes & Yes \\
School-specific time trends (linear) & No & No & Yes \\
\hline
\end{tabular}

NOTE.-The level of observation is cohort by school. All regressions include school and cohort fixed effects. In total, 11 school cohorts in the sample do not have a language track (corresponding to 727 students). Standard errors clustered at the school level are in parentheses. 
in tables 2-5 and in figure 2 suggests that the proportion of female peers is as good as random, conditional on cohort and school fixed effects.

\section{Results}

\section{A. Participation in STEM College Education}

Table 6 shows estimates of how the gender peer composition affects STEM enrollment (panel A) and completion (panel B). Because it is not obvious how to define the set of students who serve as relevant peers, we start by providing estimation results for three different definitions of school peers while keeping the sample of students fixed to those attending the math track. Column 1 considers the gender peer composition in the math track only, column 2 considers the language track only, column 3 includes both measures simultaneously, and column 4 considers the gender composition in the entire high school cohort regardless of the attended track. Overall, the estimates show that a higher proportion of female peers - independent of how we define the relevant group of peers-lowers women's probability of enrolling in and graduating from STEM college programs, while the opposite is true for men. Peers in the language track, however, have a weaker influence on women's choices. For the remainder of this paper, we will focus on peers in the math track, who arguably represent the peer group that math-track students interact with the most.

Table 7 shows estimates of how the peer composition affects STEM enrollment (panel A) and STEM degree completion (panel B) with different sets of controls. ${ }^{27}$ Column 1 shows the most basic model, which includes only the proportion of female peers, student gender, and the interaction between these variables. In columns $2-6$, we gradually include additional fixed effects, time trends, and individual-level controls. The specification in column 6 includes school fixed effects, cohort fixed effects, a large set of peerand student-level control variables, and linear, quadratic, and cubic schoolspecific time trends. Columns $2-6$ show that the magnitude of the estimates is not particularly sensitive to the exact set of included fixed effects, controls, or time trends. Column 7 shows estimates from our most restrictive specification, which includes cohort-by-school fixed effects, and shows the impact of peers on the gender gap in STEM participation.

The results in table 7 show that women exposed to a higher proportion of female peers become less likely to enroll in and graduate from STEM college programs. Men's choices also become more gender stereotypical: they are more likely to enroll in and complete STEM studies when they have a larger

\footnotetext{
${ }^{27}$ We tested whether the gender composition of peers affects the probability of dropping out of high school and the probability of enrolling in or completing college. As shown in table A2, there is no effect.
} 
Table 6

Impact of High School Gender Composition School Track and Cohort on STEM Enrollment and STEM Completion

\author{
(1)
}

$(2)$

(3)

$(4)$

Female $\times$ proportion female peers in math track

Male $\times$ proportion female peers in math track

Female $\times$ proportion female peers in language track

Male $\times$ proportion female peers in language track

Female $\times$ proportion female peers in school cohort

A. Dependent Variable: STEM Enrollment

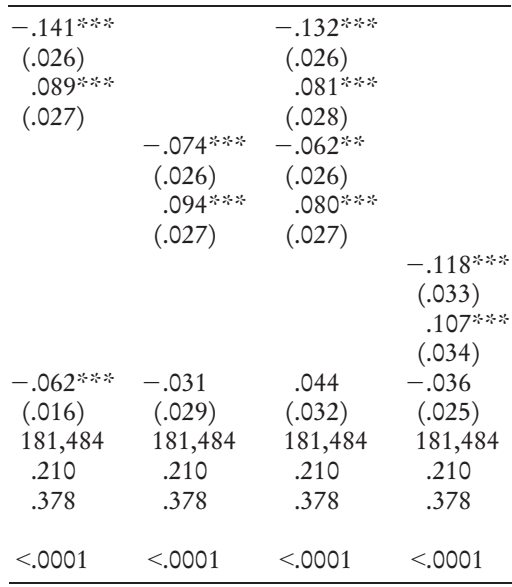

Male $\times$ proportion female peers in school cohort

Female

Observations

Mean dependent variable women

Mean dependent variable men

$p$-value from test for gender equality

of proportion female peers

B. Dependent Variable: STEM

Completion

Female $\times$ proportion female peers in math track

Male $\times$ proportion female peers in math track

Female $\times$ proportion female peers in language track

Male $\times$ proportion female peers in language track

Female $\times$ proportion female peers in school cohort

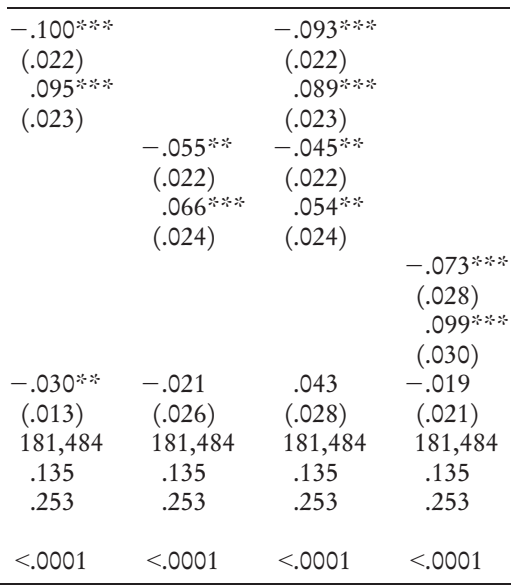

Male $\times$ proportion female peers in school cohort

Female

Observations

Mean dependent variable women

Mean dependent variable men

$p$-value from test for gender equality

of proportion female peers

NOTE.-The dependent variable in all columns of panel A is an indicator for whether the student enrolled in a STEM program in college within 20 years after high school entry. The dependent variable in all columns of panel B is an indicator for whether the student's highest completed education is at least at the college level and is within STEM. All models control for cohort fixed effects, school fixed effects, cubed cohort size, indicators for large cohort size changes compared with previous years, and a large set of individual and leave-out-mean peer controls shown in panel B of table 1 . All results are robust to the inclusion of cohortby-school fixed effects. The sample excludes those students attending a school cohort without a language track (11 school cohorts, corresponding to 727 students), which explains the difference in sample sizes between this table and table 7. Standard errors clustered at the school cohort level are in parentheses.

$* * p<.05$
$* * * 01$ 
share of female high school peers. In our preferred specification in column 4 , a 10 percentage point increase in the proportion of female high school peers lowers women's probability of enrolling in STEM by 1.4 percentage points, corresponding to a decrease of $6.4 \%$ relative to the baseline. For men, we find that a similar change in the gender composition raises STEM enrollment by 0.9 percentage points, a $2.4 \%$ change from the baseline. ${ }^{28}$

Column 7 shows our most restrictive model, which includes cohort-byschool fixed effects. We find that a 10 percentage point increase in female peers in a high school cohort raises the gender gap in STEM enrollment by 2.3 percentage points, which is equivalent to a $14 \%$ increase of the gender gap. Because we include cohort-by-school fixed effects in the model, the coefficient in column 7 identifies a change in the gender gap in STEM completion and not an absolute effect. Importantly, the effect size we identify is close to the difference between the coefficients of male and female students in the less restrictive models in columns $1-6$, which increases our confidence in the estimates obtained from the models without cohort-by-school fixed effects. ${ }^{29}$ Consequently, our estimate identified from within-cohort variation implies that exposure to more female peers within a given school cohort substantially increases gender differences in STEM choice and leads to more gender-stereotypical enrollment decisions.

Do high school peers only affect enrollment decisions, or do they have lasting effects on study completion as well? The distinction between study enrollment and completion is potentially important, as Anelli and Peri (2017) find that gender peer effects in high school affect men's initial study enrollment but have no impact on study completion or labor market outcomes. We therefore next shed light on the persistence of effects by considering the impact on the probability of STEM graduation.

Panel B in table 7 shows that the peer effects in the field of enrollment persist into actual degree completion rates. In our setting, peer effects in study enrollment are not offset by changes of college major or college dropout. Women exposed to more female peers in high school are significantly less likely to graduate with a college STEM major. A 10 percentage point increase in the proportion of female peers lowers women's STEM graduation probability by 1.0 percentage points, a $7 \%$ decrease from the baseline (col. 4). The same change raises men's probability of graduating from a STEM field by 0.9 percentage points, which is equivalent to a $3.6 \%$ increase from the baseline. Again, the point estimates of interest in columns 2-6 are very

${ }^{28}$ In addition to the linear-in-shares models shown in table 7, we have also estimated nonlinear peer effects using six bins for the proportion of female peers. In this analysis, we find relatively linear effects over the range of support that we have in the data (figs. A1, A2).

${ }^{29}$ To see this, compare the effect size of -0.233 in col. 7 with the estimate of $-0.226(-0.135-0.091)$ in col. 4 . 


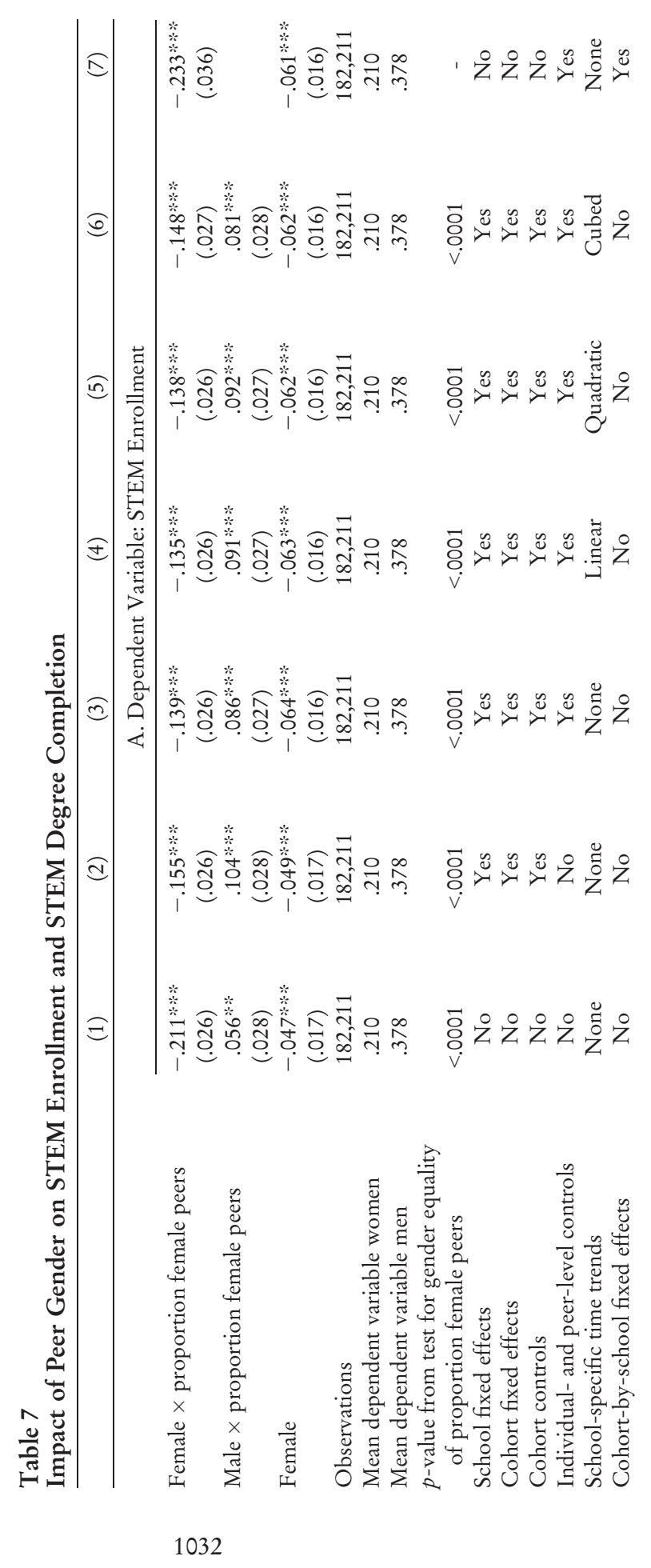




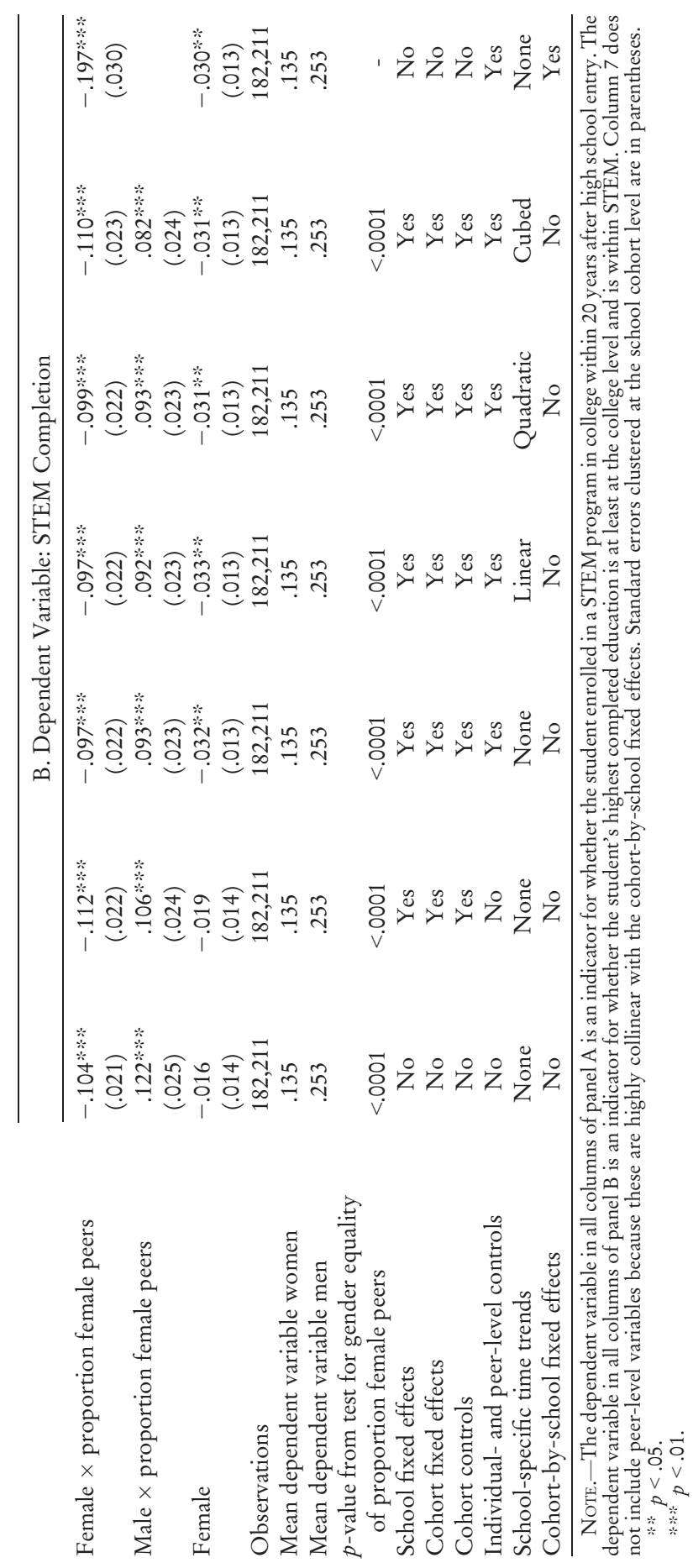


similar across models and are insensitive to the exact set of included fixed effects and time trends. Column 7 in panel B confirms that these results hold when including cohort-by-school fixed effects. Gender differences also remain present in graduation rates when we exploit whether the gender composition among peers differentially affects men and women within the same school cohort. Column 7 shows that a 10 percentage point increase in female peers raises the gender gap in STEM completion by 2 percentage points, corresponding to $17 \% .{ }^{30}$

Given the low baseline rates for women's STEM enrollment and graduation, the size of the peer effects we document in table 7 are economically significant. Taken together, we find that a higher share of female peers makes both men's and women's initial choice of study field and field of graduation more gender stereotypical.

How does the size of these peer effects compare with other factors shaping students' STEM choices? A 10 percentage point increase in female peers affects women's probability of entering STEM approximately the same as a 10 percentage point increase in the share of female professors for highmath-ability women (Carrell and Hoekstra 2010). Our effect is approximately half the size of the impact of a 1 standard deviation increase in peer ability documented in Fischer (2017), which shows that exposure to highability peers lowers women's probability of completing a STEM degree. The magnitude of our effect is also fairly close to Zölitz and Feld (forthcoming), which finds that exposure to more female peers in university teaching sections decreases women's likelihood of choosing male-dominated majors.

To understand which STEM subfields women are less attracted to when more female peers are present, we next estimate separate models in which we split STEM into four subgroups, shown in panel A of table 8: (1) biology, (2) math and physics, (3) ICT and engineering, and (4) manufacturing and construction. A comparison of the point estimates in columns 1-4 reveals that the coefficients for women are relatively similar across STEM subfields. The point estimate for ICT and engineering is marginally smaller and less precisely estimated but not significantly different from those of the

${ }^{30}$ As a robustness check, we also test whether results differ between students who attend a high school that is one of several in the municipality and those who attend the only high school in the municipality. If our estimates were driven by unobserved time-variant selection into high schools, we would expect effects to differ substantially on the basis of how much choice students have at the local level. Table A3 reports split sample regressions by the number of high schools in the municipality. For women, point estimates are very similar in regions that have only one high school in the municipality. For men, we find that the effect of peers seems to be somewhat larger in municipalities with only one high school. Although it is possible that peer effects may differ by the number of high schools in the municipality, we think that these results provide additional support for the validity of our peer effects estimates, as we find the same effects for regions where students de facto had a very limited school choice. 


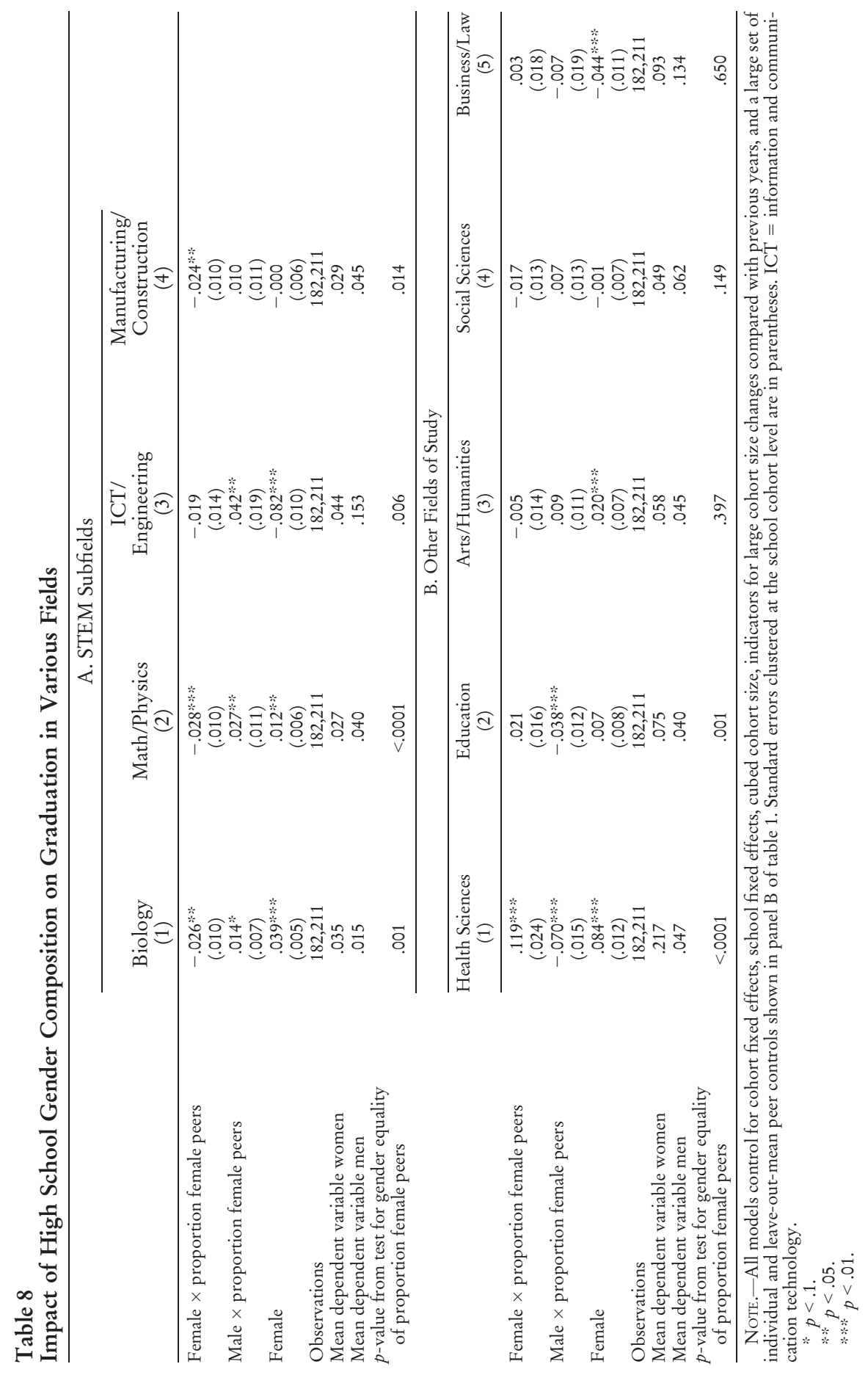


other subfields. For men, the effect of having more female peers is stronger for entering math and physics and for entering ICT and engineering, which are the most male-dominated gender-stereotypical STEM subfields.

We next ask which other study fields become more attractive to women and less attractive to men when students experience a larger share of female high school peers. In panel $\mathrm{B}$ of table 8 , we examine how the peer composition affects graduation from (1) health sciences, (2) education studies, (3) arts and humanities, (4), social sciences, and (5) business and law. Only health sciences - a field heavily dominated by women-becomes significantly more popular among women who had more female peers in high school (col. 1). ${ }^{31}$ For men, we also find that more female peers make choices that are more gender stereotypical: a larger share of female peers in high school decreases men's probability of graduating with a college major within health sciences and education studies. Columns 2-5 show that the high school gender composition does not influence women's probability of completing a college degree in education, arts and humanities, social sciences, or business and law. Consequently, our results suggest that women exposed to more female peers in high school substitute STEM studies with careers in the health sector. In section V.C, we investigate the potential labor market consequences of these education choices in more detail.

\section{B. Underlying Mechanisms and Heterogeneity}

Why does gender composition in high school affect students' decision to enter STEM fields? We shed some light on the underlying mechanism by investigating whether high school gender composition affects final high school GPA, which students use to apply for college. We also split the sample on the basis of parental educational level and field of education to learn more about whether some groups of students are more sensitive than others to the gender composition at their school. Considering heterogeneity in a parent's field of education might help us understand whether STEM role models at home moderate or perpetuate the influence of peers.

To assess the proposed mechanism, we investigate whether gender composition directly affects students' study ability or preparedness to enter STEM studies. This appears plausible, as the peer effects literature has shown that gender composition can impact students' performance (Hoxby 2000; Lavy and Schlosser 2011; Hill 2017). If gender composition affects student performance differentially depending on the student's own gender, this effect may in part explain the effects on the choice of college major. Table 9 provides estimation results supporting such a mechanism. Column 1 in table 9 shows that the gender composition does not affect women's GPA; the point estimate is tiny and not statistically significant. On the contrary, male students

${ }^{31}$ Of all women who enter health sciences, 50\% study nursing and midwifery, $20 \%$ study medicine, and $13 \%$ study therapy and rehabilitation. 


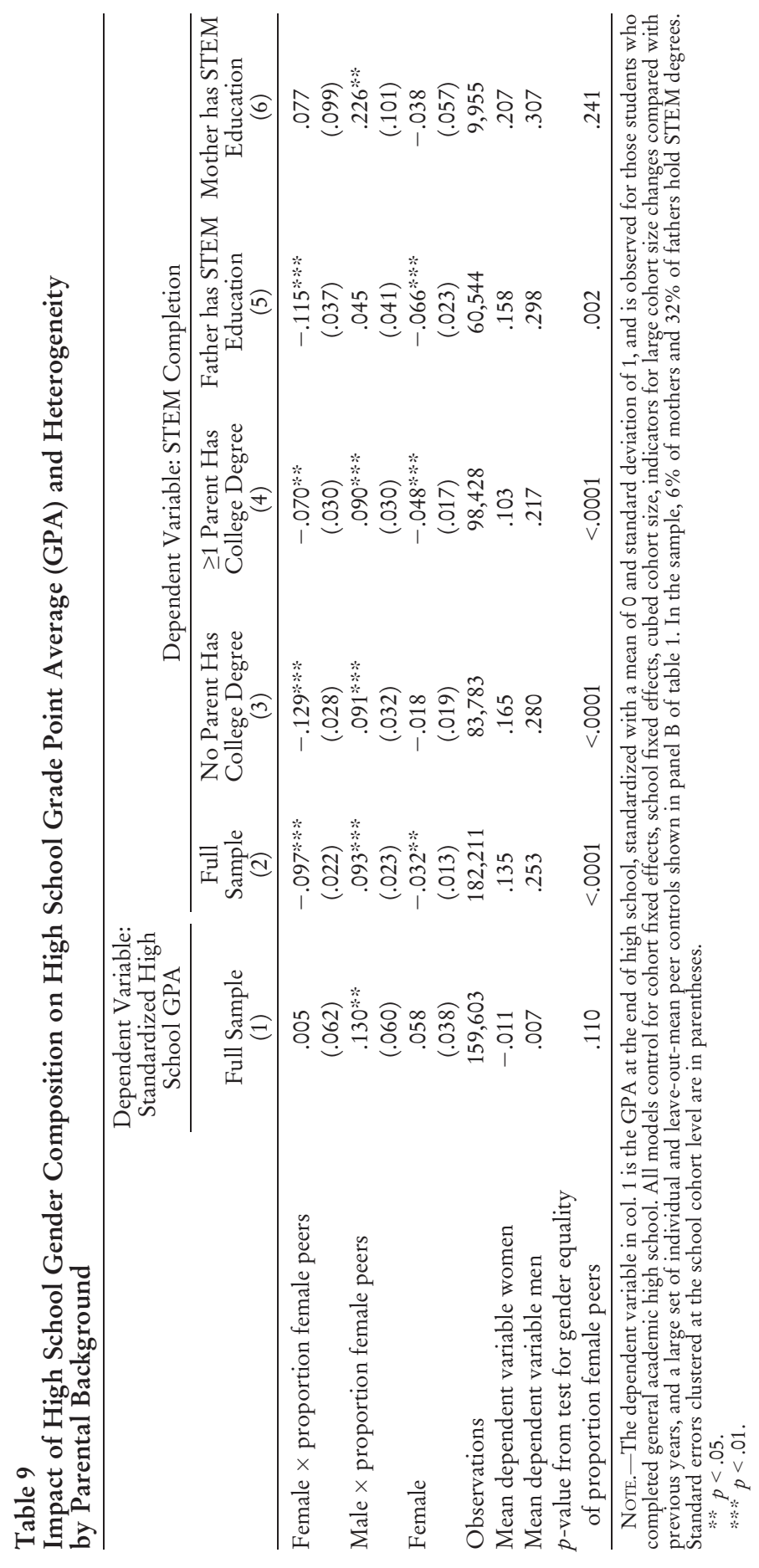


achieve a higher GPA when they are exposed to a high school cohort with more female peers. A 10 percentage point increase in female peers raises the GPA of male students by $1.3 \%$ of a standard deviation. ${ }^{32}$ Our finding is consistent with Lavy and Schlosser (2011) and Hill (2017), who show that men in high school and college achieve better grades when there are more female peers in their cohort. Importantly, the majority of STEM college programs in Denmark do not have a binding high school GPA threshold for admission. This rules out the possibility that gender composition mechanically affects STEM enrollment through the impact on male students' GPA.

The fact that male students achieve a higher GPA when a higher proportion of female peers are present may in part explain why fewer women and more men enter STEM studies in cohorts with more women. Given their higher GPAs, men might feel better prepared for STEM studies, which generally attract students with better high school grades. In contrast, women do not perform differently in high school but might infer from the gender gap in high school GPA that they are less prepared or "suited" to enter STEM studies than their male peers. These results are consistent with Zölitz and Feld (forthcoming), who also find evidence of gender-specific performance responses that can explain students' specialization choices.

Table 9 further investigates whether the influence of female peers is similar for students with less educated versus highly educated parents (cols. 3, 4) and parents with STEM educations (cols. 5, 6). Our motivation for splitting the sample by parental education is that students from nonacademic families may have less information about college majors and associated occupations and therefore be more sensitive to their peers' choices. If peers can provide information about study fields that is not available to students who have non-college-educated parents, we would expect students from families with less educated parents to be more sensitive to peer composition. Similarly, students with a STEM-educated father or mother might have better information about STEM studies and careers. If parents serve as strong role models who shape the choices of their children, we would expect that students with a (same-sex) parent in STEM are less sensitive to peer influences.

Column 3 shows estimates for the subsample of students who have parents without a college education, while column 4 shows the same model for students who have one or two parents with a college degree. ${ }^{33}$ The results show that the influence of peers is twice as strong for women with parents without a college education relative to women with college-educated parents. However, effects for men do not vary by parental education. One

${ }^{32}$ All results in table 9 are robust to the inclusion of cohort-by-school fixed effects.

${ }_{33}$ To facilitate comparison, col. 2 in table 9 reports point estimates for the full sample from our preferred specification in col. 4 of table 7. 
interpretation of these results is that women are more likely to follow the choices of their peers when they lack parents who have a greater capacity to help them find information about higher education or share their own college experiences. It is also possible that the study choice of parents who attended college provides an additional reference point that moderates the impact of peer effects in high school.

We next investigate whether effects are heterogeneous for students with a father or mother with a STEM education. Column 5 shows that the effect of peers on STEM completion is similar for women with a father in STEM and somewhat weaker and not statistically significant for men with fathers in STEM. These results suggest that men who have a STEM father are less susceptible to peer influences. Column 6 shows that these results are mirrored for women with STEM mothers. Strikingly, women with STEM mothers are not significantly affected by the peer gender composition. The point estimate is in fact positive, which suggests that STEM mothers seem to counteract the effect of peers on their daughters' specialization choice. While the group of individuals who have a mother in a STEM field is small, these results show that women who have a STEM mother as a role model are unaffected by peers. While these results remain suggestive, they could imply that access to a nonstereotypical same-sex role model in the family is more powerful in shaping women's STEM interest than the influence of high school peers.

\section{Long-Run Effects on Labor Market Outcomes}

Given our finding that high school gender composition affects the probability of enrolling in a STEM college major and completing such an education, we now want to know whether these gender peer effects also persist into occupational choice and whether they have consequences for labor earnings.

Table 10 shows the impact of high school peers on labor market outcomes 15 and 20 years after high school entry (cols. 1, 2). Fifteen years after high school entry, the median age of individuals is 29 years, and most should have completed higher education and entered the labor market. ${ }^{34}$ Table 10 shows that peers' influence on STEM field choice is persistent and closely mapped onto women's occupational choices. A larger share of female high school peers reduces the probability that women work in a STEM-related occupation, while it has no impact on men's occupational choice. A 10 percentage point increase in the proportion of female peers decreases the probability that women work in a STEM occupation 20 years after high school entry by 0.42 percentage points, a $3.9 \%$ decrease from the baseline (col. 2).

\footnotetext{
${ }^{34}$ Brenøe and Lundberg (2017) show that after age 30, the share of a cohort that has completed a college or university degree is almost constant, indicating that by age 31 most individuals have completed higher education.
} 
Table 10

Impact of High School Gender Composition on Labor Market Outcomes

\begin{tabular}{|c|c|c|c|c|}
\hline & \multicolumn{2}{|c|}{$\begin{array}{l}\text { Dependent Variable: Working } \\
\text { in STEM Occupation }\end{array}$} & \multicolumn{2}{|c|}{$\begin{array}{c}\text { Dependent Variable: Earnings } \\
\text { Percentile }\end{array}$} \\
\hline & $\begin{array}{l}\text { 11-15 Years } \\
\text { after High } \\
\text { School Entry } \\
\text { (1) }\end{array}$ & $\begin{array}{l}\text { 16-20 Years } \\
\text { after High } \\
\text { School Entry } \\
\text { (2) }\end{array}$ & $\begin{array}{l}\text { 11-15 Years } \\
\text { after High } \\
\text { School Entry } \\
\text { (3) }\end{array}$ & $\begin{array}{l}\text { 16-20 Years } \\
\text { after High } \\
\text { School Entry } \\
\text { (4) }\end{array}$ \\
\hline & \multicolumn{4}{|c|}{ A. Cohort and School Fixed Effects } \\
\hline $\begin{array}{l}\text { Female } \times \text { proportion } \\
\text { female peers }\end{array}$ & $\begin{array}{r}-.028 \\
(.019)\end{array}$ & $\begin{array}{l}-.042 * * \\
(.020)\end{array}$ & $\begin{array}{l}-4.008 * * * \\
(1.379)\end{array}$ & $\begin{array}{l}-6.608 * * * \\
(1.492)\end{array}$ \\
\hline $\begin{array}{l}\text { Male } \times \text { proportion female } \\
\text { peers }\end{array}$ & $\begin{array}{l}.027 \\
(.022)\end{array}$ & $\begin{array}{l}.038 \% \\
(.023)\end{array}$ & $\begin{array}{r}-1.511 \\
(1.417)\end{array}$ & $\begin{array}{l}-.126 \\
(1.449)\end{array}$ \\
\hline Female & $\begin{array}{l}-.123 * * * \% \\
(.012)\end{array}$ & $\begin{array}{l}-.116 * * * \\
(.013)\end{array}$ & $\begin{array}{c}-9.807 * * * \\
(.855)\end{array}$ & $\begin{array}{c}-11.654 * * * \\
(.912)\end{array}$ \\
\hline $\begin{array}{l}\text { Observations } \\
\text { Mean dependent variable } \\
\text { women }\end{array}$ & 181,022 & 178,240 & 181,012 & 178,229 \\
\hline $\begin{array}{l}\text { Mean dependent variable } \\
\text { men } \\
p \text {-value from test for } \\
\text { gender equality of } \\
\text { proportion female peers }\end{array}$ & .037 & .004 & 62.567 & 70.615 \\
\hline & & Cohort-by-Sc & ool Fixed Effec & \\
\hline $\begin{array}{l}\text { Female } \times \text { proportion } \\
\text { female peers }\end{array}$ & $\begin{array}{l}-.059 * * \\
(.027)\end{array}$ & $\begin{array}{l}-.088 * * * \\
(.029)\end{array}$ & $\begin{array}{l}-3.239 * \\
(1.892)\end{array}$ & $\begin{array}{l}-7.508 * * * \\
(2.032)\end{array}$ \\
\hline Female & $\begin{array}{l}-.122^{* * *} \\
(.012)\end{array}$ & $\begin{array}{l}-.113 * * * \\
(.013)\end{array}$ & $\begin{aligned}-9.462 * * * \\
(.864)\end{aligned}$ & $\begin{array}{c}-11.196 * * * \\
(.917)\end{array}$ \\
\hline Observations & 181,022 & 178,240 & 181,012 & 178,229 \\
\hline $\begin{array}{l}\text { Mean dependent variable } \\
\text { women }\end{array}$ & .103 & .109 & 52.178 & 56.633 \\
\hline $\begin{array}{l}\text { Mean dependent variable } \\
\text { men }\end{array}$ & .246 & .255 & 62.567 & 70.615 \\
\hline
\end{tabular}

NoTE.-The dependent variable in cols. 1 and 2 is an indicator for working in a STEM occupation; it takes a value of 1 if the individual for at least half the period works in a STEM occupation within the Danish version of International Standard Classification of Occupations codes 21, 25, 31, or 35 (science and engineering professionals, information and communications technology professionals, science and engineering associate professionals, or information and communications technicians). The dependent variable in cols. 3 and 4 is the average of the individual's labor earnings percentile during the 5-year period, calculated by year of birth and age using the entire Danish population as a reference group. All models in panel A control for school fixed effects, cubed cohort size, indicators for large cohort size changes compared with previous years, and a large set of individual and leave-out-mean peer controls shown in panel B of table 1. All models in panel B control for cohort-by-school fixed effects and individual controls. Standard errors clustered at the school cohort level are in parentheses.

$* p<.1$.

$* p<.05$.

$* * \%<<.01$. 
Men's probability of working within STEM fields is similarly affected by peer composition. This suggests that men who have more female peers become both more likely to enroll and graduate from STEM fields and are later more likely to end up working in STEM jobs.

Given these long-run effects on occupational choice, we next test whether individuals' labor earnings are affected. Does the proportion of female high school peers contribute to the gender wage gap? Columns 3 and 4 shed light on this question and show estimates for earnings 15 and 20 years after high school entry. We find that the high school gender composition has lasting effects on women's earnings but not on men's. A 10 percentage point increase in the proportion of female peers decreases women's earnings 15 years after high school entry by 0.4 percentile points-nearly a $1 \%$ decline from the baseline - and has no impact on men's earnings. Twenty years after high school entry, we still do not find any effect for men but an even larger effect of 0.66 for women. This increase in magnitude for women is in line with a similar increase in the effect on their STEM occupational participation. The estimate from our second strategy (panel B), which includes cohort-byschool fixed effects, suggests that having a 10 percentage point larger share of female high school peers increases the gender earnings gap by 0.75 percentile points, corresponding to an increase of $5.4 \%$ (col. 4). Thus, our results show that high school gender composition has lasting impacts on the gender wage gap, and one potential channel of this effect might be through the impact on STEM participation.

\section{Long-Run Effects on Fertility}

After having established that high school gender composition affects women's participation in STEM and earnings, we next examine the impact of female peers on fertility. Although fertility is an interesting outcome in itself and female peers may directly shape fertility preferences, it is also possible that starting a STEM career influences the timing and number of children. A more competitive environment, longer working hours, and lower job flexibility might make it harder to combine children and work obligations for women in STEM careers. Because of differences in work environments in terms of family friendliness, women in STEM fields may decide to have fewer or no children. In this case, changes in fertility could be interpreted as an unintended consequence of the high school gender composition that "pushed" some individuals in or out of STEM careers. Alternatively, if the high school gender composition directly affects fertility preferences, then part of the documented effects on the gender wage gap could occur because having children reduces earnings for women (Lundborg, Plug, and Rasmussen 2017; Kleven, Landais, and Søgaard 2018). In such cases, lower earnings for women should not be attributed to their lower probability of staying out of STEM fields when having more female peers but may instead be a consequence of the "career cost of children" (Adda, Dustmann, and Stevens 2017). 


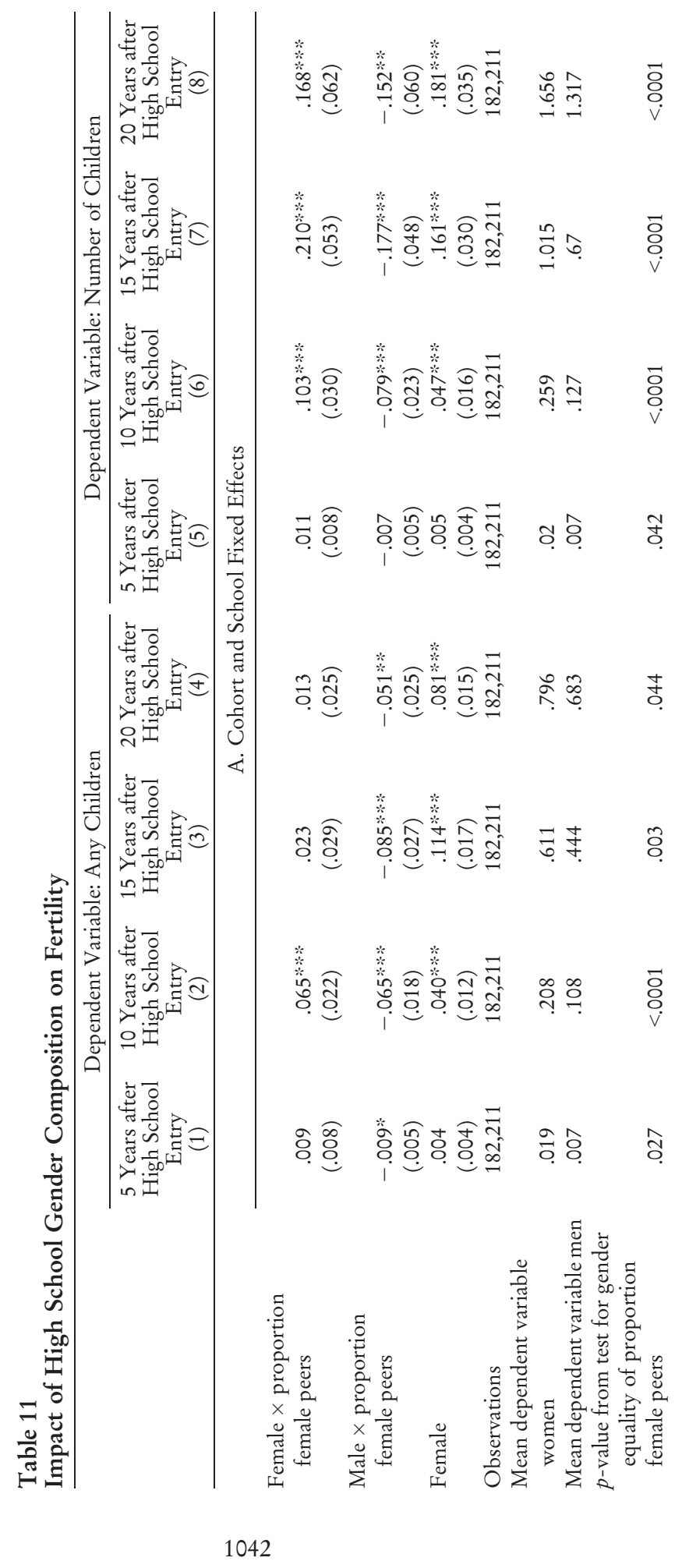




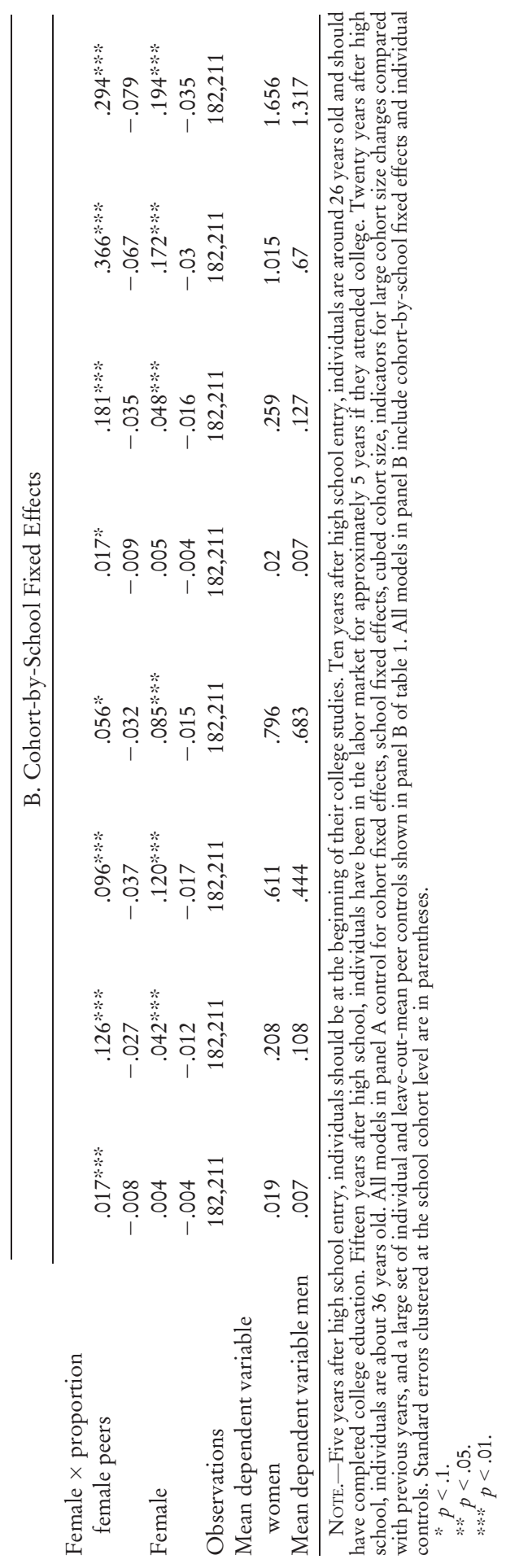


Table 11 documents the medium- and long-run consequences of high school gender composition on fertility. Columns 1-4 provide a detailed analysis on the timing of fertility effects on the extensive margin. While column 1 shows little effect on fertility during the first 5 years after high school entry, we see a clear impact on the probability of having any children within 10 years after high school entry, when individuals are around 26 years old and, for the most part, have entered the labor market (col. 2). We find that having a larger proportion of female high school peers increases women's and decreases men's probability of having any children by the age of 26 . Column 4 shows that 20 years after high school entry women are no longer less likely to have any children, but we still find a persistent effect for men. ${ }^{35}$

In columns 5-8 of table 11, we estimate effects at the intensive fertility margin by testing whether female peers affect the number of children individuals have. We find that women who had more female peers and thus were less likely to enter STEM careers have more children by the age of 36 . The increased fertility effect becomes visible shortly after the time of college completion and doubles within the first couple of years in the labor market (col. 7). By the time individuals are 36 years old, women exposed to 10 percentage points more female peers have on average 0.02 more children, an increase of about $1.0 \%$ from the baseline of 1.66 children (col. 8). For men, we find that those exposed to more female peers have significantly fewer children by age 36 .

Our results show that the proportion of female peers not only has significant impacts on study choice, occupational choice, and earnings but affects fertility as well. Strikingly, women have their first child earlier and increase the number of children they have when they have a larger share of female high school peers. If high school peers already affect men's and women's fertility preferences before choosing their field of study, women's shift from STEM to health-related studies (and the reverse for men) might partly be explained by changes in the desired number of children.

These findings on fertility raise the question of whether the negative effect of having more female high school peers on women's earnings documented in table 10 is driven by women's nonparticipation in STEM or by their increased fertility. Although we ultimately cannot distinguish between these mechanisms, our results are consistent with Kleven, Landais, and Søgaard (2018). Using Danish administrative data (similar to our data), they document that men and women experience very similar trends in labor earnings before the arrival of their first child. They show, however, that while women experience a large decline in earnings at the time of their first childbirth and still have earnings $20 \%$ below their initial level 10 years later,

${ }^{35}$ Restricting the sample to older cohorts reveals very similar effects on fertility through older ages. Therefore, the reported effects are close to effects on complete fertility, especially for women. 
men do not experience any change in their earnings after having children. Given the results of Kleven, Landais, and Søgaard (2018), our result that women who were exposed to more female peers have lower earnings could in part be due to changed fertility patterns.

Our finding that the peer gender composition causally affects the timing and number of children has not previously been documented in the existing literature. More broadly, our paper relates to a number of other studies documenting how the social environment shapes fertility decisions. Balbo and Barban (2014) use information on friendship networks in Add Health data and show that friends' childbearing is positively related to individuals' own probability of becoming a parent. Kuziemko (2006) shows that the probability of having a child rises substantially in the 2 years after a niece or nephew is born to an individual's sister but finds no impact of children born to brothers. In light of these two papers, our finding that having more female peers increases women's probability of having children earlier might, in part, occur because having more female peers (and likely more female friends) also implies having a network of people who have children sooner than when women have proportionally more male peers. Moreover, Ciliberto et al. (2016) study fertility peer effects in the workplace in Denmark and show that fertility among workplace peers of similar age and education groups is positively correlated. Relatedly, Brenøe (2018) finds that sibling sex composition does not affect the timing or number of children.

\section{Conclusion}

Using Danish administrative data, this paper shows that the gender composition of high school peers affects students' decisions to undertake STEM studies in higher education. Our results show that a higher proportion of female high school peers makes study choices more gender stereotypical. With more female peers present, women become less likely to enter STEM fields and more likely to enter health studies. Men also behave more gender stereotypically and become more prone to enter STEM studies when exposed to more female peers. For women, these gender peer effects in study choice have remarkably persistent long-run effects on occupational choice, which remain visible 20 years after high school entry. Women who by chance were exposed to more female peers are less likely to work in STEM occupations and have lower earnings 20 years after high school entry. Strikingly, high school gender composition also affects individuals' fertility.

Although our results are based on one country, our findings are consistent with the evidence provided by Hill (2017) as well as by Zölitz and Feld (forthcoming), who suggest that gender peer effects shape preferences for study fields and thereby lead students to systematically different career trajectories. Our evidence on the underlying mechanisms remains suggestive but indicates that a higher proportion of female peers affects the gender 
gap in high school GPA and may therefore foster the gender gap in STEM preparedness, which gives students reason to believe that they have a comparative advantage in a more gender-stereotypical college major. We also find that women with STEM-educated mothers are unaffected by gender composition, which suggests that salient female role models may be able to counteract peer pressure in high school. Our findings emphasize that the social environment directly affects students' decisions to specialize within STEM fields and educational and occupational choices more generally. Moreover, our results suggest that manipulating the gender composition in a given environment through affirmative action policies to achieve gender balance may have adverse and unintended consequences for fertility, gender segregation in college majors, and the labor market.

\section{Appendix}

Table A1

Complete Balancing Tests Including All Individual-Level Variables

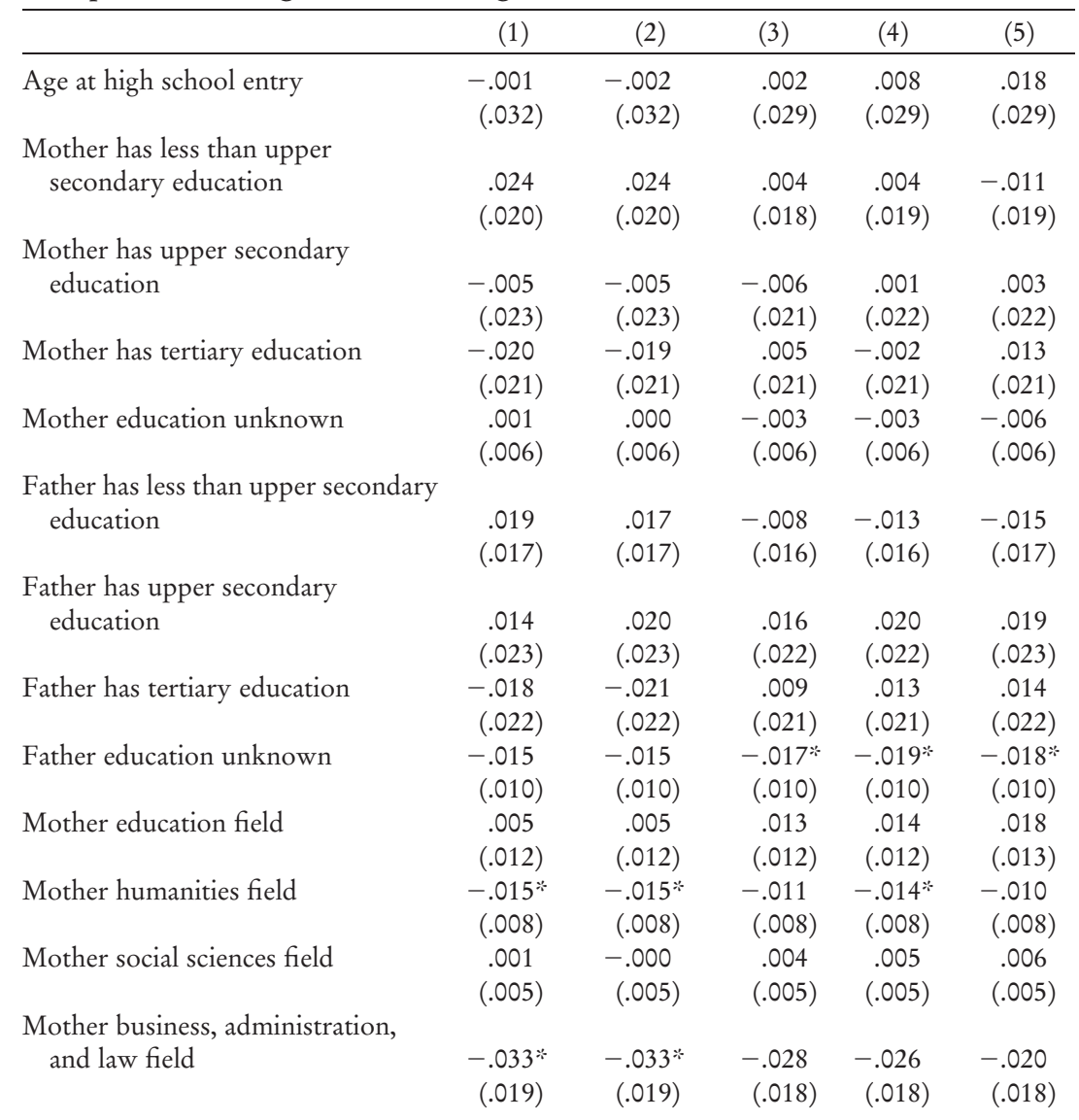


Table A1 (Continued)

\begin{tabular}{|c|c|c|c|c|c|}
\hline & (1) & (2) & (3) & (4) & (5) \\
\hline Mother STEM field & $\begin{array}{l}-.003 \\
(.009)\end{array}$ & $\begin{array}{c}-.002 \\
(.009)\end{array}$ & $\begin{array}{l}.002 \\
(.009)\end{array}$ & $\begin{array}{l}.003 \\
(.009)\end{array}$ & $\begin{array}{l}.002 \\
(.010)\end{array}$ \\
\hline Mother life sciences field & $\begin{array}{l}.000 \\
(.002)\end{array}$ & $\begin{array}{l}.000 \\
(.002)\end{array}$ & $\begin{array}{l}.000 \\
(.002)\end{array}$ & $\begin{array}{l}.000 \\
(.002)\end{array}$ & $\begin{array}{c}.001 \\
(.002)\end{array}$ \\
\hline Mother health and welfare field & $\begin{array}{l}.008 \\
(.019)\end{array}$ & $\begin{array}{l}.011 \\
(.019)\end{array}$ & $\begin{array}{c}.012 \\
(.019)\end{array}$ & $\begin{array}{l}.008 \\
(.019)\end{array}$ & $\begin{array}{l}.007 \\
(.019)\end{array}$ \\
\hline Mother service field & $\begin{array}{l}.001 \\
(.006)\end{array}$ & $\begin{array}{l}.001 \\
(.006)\end{array}$ & $\begin{array}{l}-.000 \\
(.006)\end{array}$ & $\begin{array}{l}.001 \\
(.006)\end{array}$ & $\begin{array}{l}.002 \\
(.006)\end{array}$ \\
\hline Mother no field & $\begin{array}{l}.034 * \\
(.020)\end{array}$ & $\begin{array}{l}.033 \\
(.020)\end{array}$ & $\begin{array}{l}.012 \\
(.019)\end{array}$ & $\begin{array}{l}.013 \\
(.019)\end{array}$ & $\begin{array}{l}.001 \\
(.019)\end{array}$ \\
\hline $\begin{array}{l}\text { Individual-level and high-school- } \\
\text { level controls }\end{array}$ & No & Yes & Yes & Yes & Yes \\
\hline School-specific time trends & None & None & Linear & Quadratic & Cubed \\
\hline Father education field & $\begin{array}{l}.001 \\
(.011)\end{array}$ & $\begin{array}{l}.001 \\
(.011)\end{array}$ & $\begin{array}{l}.007 \\
(.011)\end{array}$ & $\begin{array}{l}.009 \\
(.011)\end{array}$ & $\begin{array}{c}.007 \\
(.011)\end{array}$ \\
\hline Father humanities field & $\begin{array}{l}-.019 * * \% \\
(.007)\end{array}$ & $\begin{array}{l}-.020 * * \% \\
(.007)\end{array}$ & $\begin{array}{l}-.010 \\
(.007)\end{array}$ & $\begin{array}{r}-.009 \\
(.007)\end{array}$ & $\begin{array}{l}-.008 \\
(.007)\end{array}$ \\
\hline Father social sciences field & $\begin{array}{l}-.008 \\
(.005)\end{array}$ & $\begin{array}{l}-.009 * \\
(.005)\end{array}$ & $\begin{array}{l}-.008 \\
(.005)\end{array}$ & $\begin{aligned}-.009 * \\
(.005)\end{aligned}$ & $\begin{array}{l}-.008 \\
(.005)\end{array}$ \\
\hline $\begin{array}{l}\text { Father business, administration, } \\
\text { and law field }\end{array}$ & $\begin{array}{l}.010 \\
(.015)\end{array}$ & $\begin{array}{l}.012 \\
(.015)\end{array}$ & $\begin{array}{l}.022 \\
(.015)\end{array}$ & $\begin{array}{l}.026^{*} \\
(.015)\end{array}$ & $\begin{array}{l}.023 \\
(.016)\end{array}$ \\
\hline Father STEM field & $\begin{array}{l}.016 \\
(.021)\end{array}$ & $\begin{array}{l}.017 \\
(.021)\end{array}$ & $\begin{array}{l}.011 \\
(.020)\end{array}$ & $\begin{array}{l}.005 \\
(.020)\end{array}$ & $\begin{array}{l}.008 \\
(.021)\end{array}$ \\
\hline Father life sciences field & $\begin{array}{l}.004 \\
(.007)\end{array}$ & $\begin{array}{l}.005 \\
(.007)\end{array}$ & $\begin{array}{l}.007 \\
(.007)\end{array}$ & $\begin{array}{l}.014 \% \% \\
(.007)\end{array}$ & $\begin{array}{l}.013 \% \\
(.007)\end{array}$ \\
\hline Father health and welfare field & $\begin{array}{r}-.008 \\
(.010)\end{array}$ & $\begin{array}{r}-.008 \\
(.010)\end{array}$ & $\begin{array}{c}-.004 \\
(.010)\end{array}$ & $\begin{array}{c}-.004 \\
(.010)\end{array}$ & $\begin{array}{r}-.002 \\
(.010)\end{array}$ \\
\hline Father service field & $\begin{array}{c}.005 \\
(.009)\end{array}$ & $\begin{array}{c}.005 \\
(.009)\end{array}$ & $\begin{array}{c}.004 \\
(.009)\end{array}$ & $\begin{array}{c}.001 \\
(.009)\end{array}$ & $\begin{array}{r}-.003 \\
(.009)\end{array}$ \\
\hline Father no field & $\begin{array}{c}.015 \\
(.017)\end{array}$ & $\begin{array}{c}.015 \\
(.018)\end{array}$ & $\begin{array}{c}-.014 \\
(.016)\end{array}$ & $\begin{array}{r}-.017 \\
(.017)\end{array}$ & $\begin{array}{r}-.017 \\
(.017)\end{array}$ \\
\hline Child is adopted & $\begin{array}{c}.004 \\
(.004)\end{array}$ & $\begin{array}{l}.004 \\
(.004)\end{array}$ & $\begin{array}{c}.003 \\
(.004)\end{array}$ & $\begin{array}{c}.003 \\
(.004)\end{array}$ & $\begin{array}{c}.003 \\
(.004)\end{array}$ \\
\hline Lives with both parents at age 10 & $\begin{array}{l}.006 \\
(.015)\end{array}$ & $\begin{array}{c}.010 \\
(.015)\end{array}$ & $\begin{array}{c}.010 \\
(.015)\end{array}$ & $\begin{array}{c}.006 \\
(.015)\end{array}$ & $\begin{array}{c}.005 \\
(.014)\end{array}$ \\
\hline First-generation immigrant & $\begin{array}{c}.001 \\
(.005)\end{array}$ & $\begin{array}{c}.000 \\
(.005)\end{array}$ & $\begin{array}{r}-.004 \\
(.005)\end{array}$ & $\begin{array}{c}-.001 \\
(.004)\end{array}$ & $\begin{array}{r}-.001 \\
(.005)\end{array}$ \\
\hline Second-generation immigrant & $\begin{array}{c}.004 \\
(.005)\end{array}$ & $\begin{array}{c}.003 \\
(.005)\end{array}$ & $\begin{array}{r}-.004 \\
(.004)\end{array}$ & $\begin{array}{r}-.003 \\
(.004)\end{array}$ & $\begin{array}{r}-.004 \\
(.004)\end{array}$ \\
\hline Firstborn & $\begin{array}{r}-.039 * \\
(.022)\end{array}$ & $\begin{array}{r}-.041^{*} \\
(.022)\end{array}$ & $\begin{array}{r}-.038 \% \\
(.022)\end{array}$ & $\begin{array}{c}-.024 \\
(.022)\end{array}$ & $\begin{array}{r}-.009 \\
(.023)\end{array}$ \\
\hline Number of siblings & $\begin{array}{l}.007 \\
(.039)\end{array}$ & $\begin{array}{r}-.004 \\
(.039)\end{array}$ & $\begin{array}{c}-.028 \\
(.038)\end{array}$ & $\begin{array}{r}-.038 \\
(.039)\end{array}$ & $\begin{array}{r}-.059 \\
(.041)\end{array}$ \\
\hline Number of siblings squared & $\begin{array}{r}-.029 \\
(.267)\end{array}$ & $\begin{array}{c}-.100 \\
(.266)\end{array}$ & $\begin{array}{r}-.345 \\
(.257)\end{array}$ & $\begin{array}{c}-.402 \\
(.265)\end{array}$ & $\begin{array}{c}-.569 \% * \\
(.282)\end{array}$ \\
\hline Mother's age at birth & $\begin{array}{c}.267 \\
(.265)\end{array}$ & $\begin{array}{c}.308 \\
(.265)\end{array}$ & $\begin{array}{c}.274 \\
(.250)\end{array}$ & $\begin{array}{c}.063 \\
(.248)\end{array}$ & $\begin{array}{r}-.035 \\
(.253)\end{array}$ \\
\hline
\end{tabular}


Table A1 (Continued)

\begin{tabular}{lccccc}
\hline & $(1)$ & $(2)$ & $(3)$ & $(4)$ & $(5)$ \\
\hline Mother's age at birth squared & 15.921 & 17.982 & 14.983 & 7.406 & 1.763 \\
& $(13.486)$ & $(13.493)$ & $(12.545)$ & $(12.380)$ & $(12.625)$ \\
Mother $<22$ years at birth & -.013 & -.015 & -.011 & -.001 & .006 \\
& $(.016)$ & $(.016)$ & $(.016)$ & $(.016)$ & $(.016)$ \\
Mother's age unknown & .003 & .003 & .001 & .005 & .004 \\
& $(.005)$ & $(.005)$ & $(.005)$ & $(.005)$ & $(.005)$ \\
School-level controls & No & Yes & Yes & Yes & Yes \\
School-specific time trends & None & None & Linear Quadratic & Cubed
\end{tabular}

NOTE.-Data are based on 190 separate regressions. Each cell in this table is estimated with a separate regression including school and cohort fixed effects. The dependent variable in each cell is the proportion of female high school peers. School-level controls included in cols. 2-5 are an indicator for whether any student in the cohort is older than 20 years at high school entry, dummies for number of students without information on gender (ranging from 0 to 2), indicators for large changes in cohort size compared with previous years, the female share in the language track, an indicator for whether the high school has no language track, indicators for exposure to experiment on course curriculum, and cubed cohort size. Standard errors in parentheses are clustered at the school cohort level.

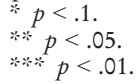

Table A2

Impact of Peer Gender on High School Graduation, College Enrollment, and Higher Education Degree Completion

\begin{tabular}{lccc}
\hline & $\begin{array}{c}\text { Completed } \\
\text { Academic High } \\
\text { School } \\
(1)\end{array}$ & $\begin{array}{c}\text { Ever Enrolled in } \\
\text { Higher Education } \\
(2)\end{array}$ & $\begin{array}{c}\text { Completed Higher } \\
\text { Education Degree } \\
(3)\end{array}$ \\
\hline Female proportion female peers & .017 & -.010 & .000 \\
Male $\times$ proportion female peers & $(.017)$ & $(.024)$ & $(.027)$ \\
& .017 & -.030 & -.035 \\
Female & $(.017)$ & $(.022)$ & $(.026)$ \\
$N$ & $.024 * *$ & .005 & $.045^{* * *}$ \\
Mean & $(.010)$ & $(.014)$ & $(.016)$ \\
$p$-value from test for gender & 182,211 & 182,211 & 182,211 \\
$\quad$ equality of proportion female & .909 & .789 & .677 \\
peers & & & .315 \\
\hline
\end{tabular}

NotE.-The dependent variable in col. 1 is equal to 1 if the student completed academic high school within 5 years after high school entry. The dependent variable in col. 2 is equal to 1 if the student ever enrolled in college studies, and the dependent variable in col. 3 is equal to 1 if the student ever completed any college education. All models control for school-specific time trends, cohort fixed effects, school fixed effects, cubed cohort size, indicators for large cohort size changes compared with previous years, and a large set of individual and leave-out-mean peer controls shown in panel B of table 1. Standard errors clustered at the school cohort level are in parentheses.

$* * p<.05$
$* * * 01$ 
Table A3

Robustness Check: Main Results by Number of Schools in the Municipality

\begin{tabular}{lccc}
\hline & \multicolumn{3}{c}{ Dependent Variable: STEM Completion } \\
\cline { 2 - 4 } & $\begin{array}{c}\text { Full } \\
\text { Sample } \\
(1)\end{array}$ & $\begin{array}{c}\text { Municipality with } \\
\text { Only 1 High School } \\
(2)\end{array}$ & $\begin{array}{c}\text { Municipality with } \\
\geq 2 \text { High Schools } \\
(3)\end{array}$ \\
\hline Female $\times$ proportion female peers & $-.097 * * *$ & $-.088^{* * * *}$ & $-.097 * * *$ \\
& $(.022)$ & $(.030)$ & $(.032)$ \\
Male $\times$ proportion female peers & $.092 * * *$ & $.107 * * *$ & $.064 \% *$ \\
Female & $(.023)$ & $(.032)$ & $(.033)$ \\
& $-.033 * *$ & $-.036 *$ & $-.037 \% *$ \\
Observations & $(.013)$ & $(.019)$ & $(.019)$ \\
Mean & 182,211 & 99,599 & 82,612 \\
$p$-value from test for gender equality & .200 & .200 & .199 \\
of proportion female peers & $<.0001$ & .001 & .046 \\
\hline
\end{tabular}

NoтE.-All models control for school-specific time trends, cohort fixed effects, school fixed effects, cubed cohort size, indicators for large cohort size changes compared with previous years, and a large set of individual and leave-out-mean peer controls shown in panel B of table 1. Standard errors clustered at the school cohort level are in parentheses.

$* p<.1$.

$* * p<.05$

$* * * p<.01$. 


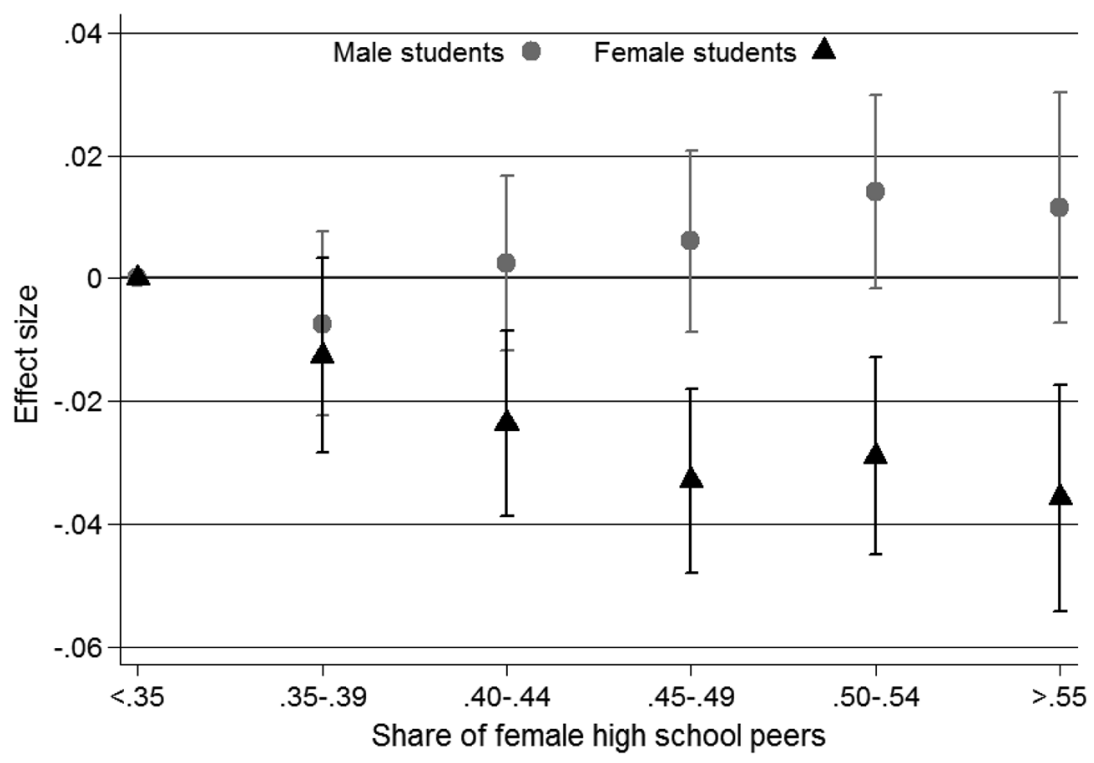

FIG. A1.-High school gender composition and STEM enrollment nonlinear effects. This graph shows point estimates obtained from ordinary least squares regression. Instead of including the continuous measure of the proportion of female high school peers interacted with the gender dummy, this regression includes five dummies for the high school gender composition interacted with gender. The dependent variable is STEM study enrollment. Vertical lines show $95 \%$ confidence intervals. The model controls for school-specific linear time trends, cohort fixed effects, school fixed effects, cubed cohort size, indicators for large cohort size changes compared with previous years, and a large set of individual and leave-out-mean peer controls shown in panel B of table 1 . 


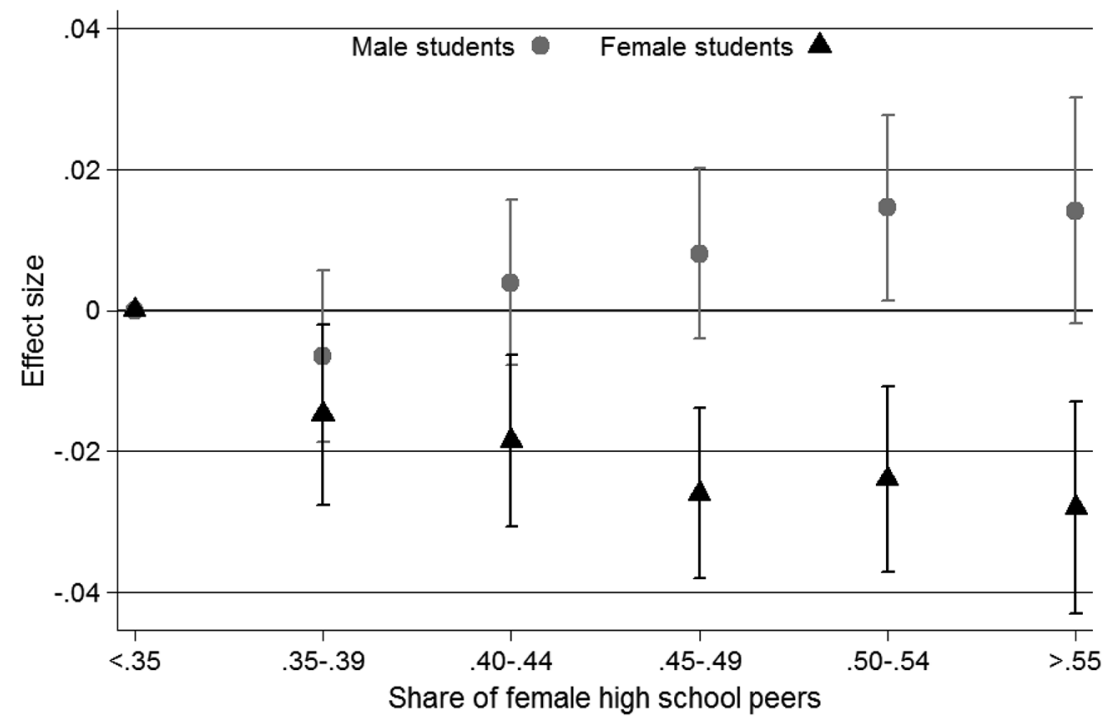

FIG. A2.- - High school gender composition and STEM graduation: nonlinear effects. This graph shows point estimates obtained from ordinary least squares regression. Instead of including the continuous measure of the proportion of female high school peers interacted with the gender dummy, this regression includes five dummies for the high school gender composition interacted with gender. The dependent variable is STEM graduation. Vertical lines show 95\% confidence intervals. The model controls for school-specific linear time trends, cohort fixed effects, school fixed effects, cubed cohort size, indicators for large cohort size changes compared with previous years, and a large set of individual and leave-out-mean peer controls shown in panel B of table 1 .

\section{References}

Adda, Jérôme, Christian Dustmann, and Katrien Stevens. 2017. The career costs of children. Journal of Political Economy 125, no. 2:293-337.

Altonji, Joseph G., Todd E. Elder, and Christopher R. Taber. 2005. Selection on observed and unobserved variables: Assessing the effectiveness of Catholic schools. Journal of Political Economy 113, no. 1:151-84.

Anelli, Massimo, and Giovanni Peri. 2017. The effects of high school peers' gender on college major, college performance and income. Economic Journal 129, no. 618:553-602.

Angrist, Joshua D. 2014. The perils of peer effects. Labour Economics 30:98-108.

Autor, David, David Figlio, Krzysztof Karbownik, Jeffrey Roth, and Melanie Wasserman. 2019. Family disadvantage and the gender gap in 
behavioral and educational outcomes. American Economic Journal: Applied Economics 11, no. 3:338-81.

Balbo, Nicoletta, and Nicola Barban. 2014. Does fertility behavior spread among friends? American Sociological Review 79, no. 3:412-31.

Bifulco, Roberto, Jason M. Fletcher, and Stephen L. Ross. 2011. The effect of classmate characteristics on post-secondary outcomes: Evidence from the add health. American Economic Journal: Economic Policy 3, no. 1:25-53.

Brenøe, Anne A. 2018. Brothers increase women's gender conformity. Working Paper no. 294, University of Zurich.

Brenøe, Anne A., and Shelly Lundberg. 2017. Gender gaps in the effects of childhood family environment: Do they persist into adulthood? European Economic Review 109:42-62.

Carrell, Scott E., and Mark L. Hoekstra. 2010. Externalities in the classroom: How children exposed to domestic violence affect everyone's kids. American Economic Journal: Applied Economics 2, no. 1:211-28.

Carrell, Scott E., Mark L. Hoekstra, and Elira Kuka. 2018. The long-run effects of disruptive peers. American Economic Review 108, no. 11:3377-415.

Ciliberto, Federico, Amalia R. Miller, Helena S. Nielsen, and Marianne Simonsen. 2016. Playing the fertility game at work: An equilibrium model of peer effects. International Economic Review 57, no. 3:827-56.

De Giorgi, Giacomo, Michele Pellizzari, and William G. Woolston. 2012. Class size and class heterogeneity. Journal of the European Economic Association 10, no. 4:795-830.

Epple, Dennis, and Richard E. Romano. 2011. Peer effects in education: A survey of the theory and evidence. Handbook of Social Economics 1, no. 11:1053-163.

Feld, Jan, and Ulf Zölitz. 2017. Understanding peer effects: On the nature, estimation, and channels of peer effects. Journal of Labor Economics 35, no. 2:387-428.

Fischer, Stefanie. 2017. The downside of good peers: How classroom composition differentially affects men's and women's STEM persistence. $\mathrm{La}-$ bour Economics 46:211-26.

Guryan, Jonathan, Kory Kroft, and Matthew J. Notowidigdo. 2009. Peer effects in the workplace: Evidence from random groupings in professional golf tournaments. American Economic Journal: Applied Economics 1, no. 4:34-68.

Hanushek, Eric A., Jacob F. Kain, John M. Markman, and Steven G. Rivkin. 2003. Does peer ability affect student achievement? Journal of Applied Econometrics 18, no. 5:527-44.

Hill, Andrew J. 2015. The girl next door: The effect of opposite gender friends on high school achievement. American Economic Journal: Applied Economics 7, no. 3:147-77.

. 2017. The positive influence of female college students on their male peers. Labour Economics 44:151-60. 
Hoxby, Caroline M. 2000. Peer effects in the classroom: Learning from gender and race variation. NBER Working Paper no. 7867, National Bureau of Economic Research, Cambridge, MA.

Hoxby, Caroline M., and Gretchen Weingarth. 2005. Taking race out of the equation: School reassignment and the structure of peer effects. NBER Working Paper no. 7867, National Bureau of Economic Research, Cambridge, MA.

Jackson, C. Kirabo. 2016. The effect of single-sex education on test scores, school completion, arrests, and teen motherhood: Evidence from school transitions. NBER Working Paper no. 22222, National Bureau of Economic Research, Cambridge, MA.

Joensen, Juanna S., and Helena S. Nielsen. 2016. Mathematics and gender: Heterogeneity in causes and consequences. Economic Journal 126, no. 593:1129-63.

Kahn, Shulamit, and Donna Ginther. 2017. Women and STEM. NBER Working Paper no. 23525, National Bureau of Economic Research, Cambridge, MA.

Kleven, Henrik, Camille Landais, and Jakob E. Søgaard. 2018. Children and gender inequality: Evidence from Denmark. NBER Working Paper no. 24219, National Bureau of Economic Research, Cambridge, MA.

Kuziemko, Ilyana. 2006. Is having babies contagious? Estimating fertility peer effects between siblings. Unpublished manuscript, Harvard University, Cambridge, MA.

Lavy, Victor, M. Daniele Paserman, and Analia Schlosser. 2012. Inside the black box of ability peer effects: Evidence from variation in the proportion of low achievers in the classroom. Economic Journal 122, no. 559:20837.

Lavy, Victor, and Analia Schlosser. 2011. Mechanisms and impacts of gender peer effects at school. American Economic Journal: Applied Economics 3, no. 2:1-33.

Lee, Soohyung, Lesley J. Turner, Seokjin Woo, and Kyunghee Kim. 2014. All or nothing? The impact of school and classroom gender composition on effort and academic achievement. NBER Working Paper no. 20722, National Bureau of Economic Research, Cambridge, MA.

Lefgren, Lars. 2004. Educational peer effects and the Chicago public schools. Journal of Urban Economics 56, no. 2:169-91.

Lundborg, Petter, Erik Plug, and Astrid W. Rasmussen. 2017. Fertility effects on female labor supply: IV evidence from IVF treatments. American Economic Review 107, no. 6:1611-37.

Merlino, L. P., Max F. Steinhardt, and Liam Wren-Lewis. 2019. More than just friends? School peers and adult interracial relationships. Journal of Labor Economics 37, no. 3:663-713.

OECD (Organization for Economic Cooperation and Development). 2016. Education at a glance 2016: OECD indicators. Paris: OECD. 
Oosterbeek, Hessel, and Reyn van Ewijk. 2014. Gender peer effects in university: Evidence from a randomized experiment. Economics of Education Revierw 38:51-63.

Schneeweis, Nicole, and Martina Zweimüller. 2012. Girls, girls, girls: Gender composition and female school choice. Economics of Education Review 31, no. 4:482-500.

Sohn, Hosung. 2016. Mean and distributional impact of single-sex high schools on students' cognitive achievement, major choice, and test-taking behavior: Evidence from a random assignment policy in Seoul, Korea. Economics of Education Revierw 52:155-75.

UIS (UNESCO Institute for Statistics). 2012. International standard classification of education: ISCED 2011. Montreal: UIS.

Vigdor, Jacob, and Thomas Nechyba. 2006. Peer effects in North Carolina public schools. In Schools and the Equal opportunities problem, ed. Ludger Woessmann and Paul E. Peterson. Cambridge, MA: MIT Press.

Whitmore, Diane. 2005. Resource and peer impacts on girls' academic achievement: Evidence from a randomized experiment. American Economic Review 95, no. 2:199-203.

Zölitz, Ulf, and Jan Feld. Forthcoming. The effect of peer gender on major choice in business school. Management Science. 